Claus Secher

\title{
Kunsten og den forvaltede verden
}

En analyse af Theodor $\mathrm{W}$. Adornos æstetiske teori og litteraturkritiske praksis

\section{Indledning}

Jeg har med denne analyse villet give en behandling af Adornos æstetiske teori. Det har været et yderst vanskeligt arbejde, fordi Adornos planlagte hovedværk om kunst, $\ddot{A}$ sthetische Theorie aldrig blev fuldendt fra forfatterens side før hans dod i 1969. Den kæmpebog, der i 1970 blev udgivet af Gretel Adorno og Rolf Tiedemann, bærer præg af at være et ufuldendt værk.

I forvejen skyede Adorno den systematiske klare opbygning, fordi den ville være et forræderi mod en kritisk teori, hvis væsentligste sigte var en kamp mod abstraktioner og systematisk tænkning. Men "Asthetische Theories" uoverskuelighed er ikke blot et resultat af denne holdning, men først og fremmest konsekvensen af, at den aldrig blev færdiggiort.

Udgiverne har fornuftigt nok ikke provet at rekonstruere ud fra et komposionelt princip, men har ladet bogen fremstå som en samling af fragmenter, og blot forsynet de enkelte afsnit med overskrifter, som dog ikke tilnærmelsesvis dækker de mange tankespring inden for afsnittene. At ville gå kronologisk frem ville derfor blot være at reproducere det eksisterende kaos. Jeg har derfor valgt at gennemgå æstetikken ud fra en behandling af dens væentligste begreber og samle materialet under disse uden at tage hensyn til deres placering i Adornos "fremstilling".

Da Adornos æstetiske teori ganske klart bygger på en filosofisk teori, har jeg fundet det nødvendigt at belyse denne i korte træk. Jeg har valgt at gøre det ud fra en analyse af de væsentligste tanker i Horkheimers og Adornos filosofiske hovedværk Dialektik der Aufklärung, der bortset fra et enkelt afsnit blev skrevet i 1944, og som udkom i 1947.

Det er min teori, at Adorno i sine senere værker fastholder den filosofiske grundposition fra Dialektik der Aufklärung, og jeg har som dokumentation refereret en lille artikel "Wozu noch Philosophie" og påvist den lige linje op til den æstetiske teori. I denne gennemgang af Adornos filosofiske position har jeg skitseret Adornos forhold til en bestemt tysk filosofisk tradition. Derpå har jeg inddraget æstetikken og påvist dens placering inden for Frankturterskolens kritiske teori og antydet dens relationer til den tyske æstetiske tradition. Først på dette tidspunkt kastede jeg mig for alvor over $\ddot{A}$ sthetische Theorie. 


\section{4}

Det er klart, at det har været umuligt at komme ind på alle de problemer, Adorno rejser. Jeg har derfor som nævnt kun beskæftiget mig med hovedbegreberne. Desuden har det specielt været opfattelsen af litteraturen, som har interesseret mig, og jeg har derfor koncentreret mig mest om de steder, hvor Adorno eksplicit refererer til litterære eksempler. Adornos musiksociologi virker uhyre spændende, men går noget hen over hovedet på en musikamatør som mig. De mange musikeksempler er derfor ikke blevet behandlet.

For at gøre Adornos litteraturopfattelse tydeligere har jeg inddraget nogle af hans spændende litterære essays fra de 3 bind Noten zur Literatur. Da de netop skal tjene til illustration af Adornos æstetiske teori, har jeg ikke behandlet dem separat og i deres helhed, men draget dele af dem ind som eksempelmateriale, når jeg mente, at de kunne belyse de æste tiske grundbegreber.

Jeg har først analyseret Adornos opfattelse af kunstens forhold til samfundet og diskuteret spørgsmålet om engagement versus autonomi. Dette ledede over $i$ en definition af kunstens forhold til ideologien og til en samfundsmæssig subjekt-objekt-problematik. Fra det generelle plan bevægede jeg mig ned til en diskussion af det dialektiske forhold mellem form og indhold og mellem harmoni og disharmoni for atter at placere denne $i$ en opfattelse af naturens og kulturens nuværende funktioner.

Derefter har jeg analyseret Adornos sprogteori og sat det kunstneriske sprog $\mathrm{i}$ relation til det dagligdags kommunikative. Sprogtænkningen opsumerer på en måde alle de væsentlige tendenser i Adornos æstetik og er her blevet brugt til en foreløbig samling af trådene.

Endelig har jeg placeret Adorno inden for en rstetisk og specielt litterær tradition ved at gennemgå hans kritik af både den klassicistiske og realistiske kunst og æstetik for til sidst at påvise hans forankring i et modernistisk kunstsyn.

Til slut har jeg foretaget en kritik af Adorno, som, til trods for at den yder ham hæder for hans filosofiske og æstetiske analyser, implicerer en afstandtagen fra såvel den kritiske teoris filosofiske udgangspunkt som dens konsekvenser for Adornos æstetiske teori.

\section{Den filosofiske udgangsposition}

Bag Adornos arbejder på forskellige videnskabelige felter ligger en ganske bestemt kritisk, filosofisk teori. For at forstå hans æstetiske teori og specielt hans forhold til litteraturen har jeg fundet det nodvendigt kort at skitsere hans baggrund og nogle af hans vasentligste tanker om det nutidige (vesterlandske) samfund.

Adorno arbejdede som bekendt under "Institut für Sozialforschung", . der oprettedes i Frankfurt i 1930. Da Hitler overtog magten, flygtede han 
sammen med andre af Frankfurterskolens kendte navne (Horkheimer, Marcuse, Benjamin o.a.) og kom til U.S.A., hvor han pả Columbia-universitetet i samarbejde med Horkheimer fortsatte instituttets sociologiske og filosofiske arbejde, som kulminerede i det fælles værk Dialektik der Aufklärung.

Adornos filosofiske samfundsfortolkning er således skabt under indtryk af de tyske arbejderes kapitulation over for Hitler, og arbejdernes tilsyneladende integration i det monopolkapitalistiske U.S.A. Det vil sige, at de tydelige tendenser i marxistisk retning, der prægede Frankfurterskolens, specielt Horkheimers tidlige arbejder (1) nu blev opgivet til fordel for en rent negativ kritisk teori. Den russiske stalinisme medvirkede også stærkt til denne udvikling.

I Dialektik der Aufklärung afholder forfatterne sig bevidst fra at skitsere en alternativ, videnskabelig samfundsmodel, ligesom de viser den yderste askese over for refleksioner over revolutionær praksis. Det forhindrer dog ikke bogen $i$ at være et af hovedværkerne $i$ opgøret med den positivistiske videnskab og den teknologiske "fornuft", og jeg vil derfor trække nogle af dens hovedpunkter frem, fordi de resultater, Horkheimer og Adorno når frem til, fastholdes i Adornos senere produktion.

Titlen, oplysningens dialektik, rummer værkets hovedidé, at begreberne oplysning og fornuft indeholder en fundamental og skæbnesvanger tvetydighed. Gennem oplysningen frigjorde mennesket sig fra den ydre naturtvang (Mythos): "Oplysningens program gik ud på en afmystificering af verden. Den ville afløse myterne og styrte indbildningen gennem viden" (Dialektik der Aufklärung p. 9 (fremover D.d.A.) (3).

Denne frigørelsesproces resulterede $i$, at mennesket underlagde sig naturen, såvel den ydre som den indre, menneskelige, således at oplysningen reelt kom til at bygge på magt og undertrykkelse: "Oplysningen forholder sig til tingene som diktatoren til menneskene. Videnskabsmanden kender tingene, for så vidt som han kan producere dem". (D.d.A. p. 15)(4).

Naturundertrykkelsens konsekvens er i produktionsprocessen arbejdsdelingen (i modsætning til mytens stammefællesskab), i de menneskelige relationer en tingsliggørelse, hvor mennesket formes efter vareproduktionen. På det videnskabelige område gøres den formaliserede logik og matematikken til den videnskabelige fornuft i sig selv. Disse videnskabers abstrakte karakter sættes som samfundsnormer, hvorved det konkrete og menneskelige, d.v.s. menneskets natur, undertrykkes.

I denne forstand er oplysningsbegrebet (og den dertil knyttede teknologiske ratio) negativ, fordi det teknologiske fremskridt er blevet betalt med en stadig større menneskelig undertrykkelse. Men oplysningen er, som titlen siger, en tvetydig størrelse, der også rummer mulige 
progressive tendenser. Oplysningens hidtidige resultat har været en fortrængning af den menneskelige natur som resultat af en tingsliggiort tænkning. Men hvis oplysningen korrigerer sig selv og indtænker naturen $\mathrm{i}$ mennesket vil den blive en revolutionær teori, der vender sig mod magthaverne: "Ved at tænke naturen ind i subjektet, $i$ hvilken proces al kulturs miskendte sandhed ligger begravet, er oplysning overhovedet magtens modsætning”. (D.d.A. p. 47)(5).

Med væksten i produktivkræfterne er muligheden for frigørelse vokset proportionalt med den reelle undertrykkelse: "Elendigheden som modsæetning mellem magt og afmagt vokser til det uhyrlige samtidig med evnen til for altid at afskaffe enhver elendighed". (D.d.A. p. 45)(6). Dette paradoks, som er konsekvensen af den skitserede rationelle, videnskabelige holdning, er Horkheimer og Adorno i stand til at formulere, men med deres skepsis over for muligheden af alternativ videnskabelig og politisk praksis ikke på nogen måde i stand til at overskride (7).

"Dialektik der Aufklärung" er langt mere en analyse af en bestemt videnskabelig holdning og dens konsekvenser end en historisk, for slet ikke at sige marxistisk analyse af et bestemt historisk forløb. Sảledes læses Odysséen frit, men yderst spændende, som en myte om menneskets frigørelse fra naturen og mytiske fortolkninger på vej mod en rationel, videnskabelig og borgerlig holdning. Odysseus-myten er således historien om en bestemt videnskabelig holdnings genesis.

Hos Kant kulminerer den borgerlige filosofi, samtidig med at dens modsætninger bliver åbenbare. På den ene side underlægger mennesket sig gennem sin fornuft naturen, som struktureres i nodvendige naturlove. På den anden side hævdes menneskets etiske frihed (det kategoriske imperativ) uafhængigt af naturen. Ved således at give moralen et hjørne for sig selv uden for den historiske situation, bliver moralen en blot sentimental størrelse, som ingen reel indflydelse øver imod den almindelige natur- og menneskeundertrykkelse. Kant prøver at begrunde moralen ud fra andet end den materielle interesse, men opnår derved blot at moralen ingen rolle spiller, når de materielle interesser virkelig står på spil (8).

Mens Kant således forskønner den borgerlige samfundsmæssige virkelighed, bekender Marquis de Sade og Nietzsche sig åbent til samfundets onde kræfter. De forholder sig accepterende til den videnskabelige undertrykkelse ved bevidst at føre den ud i det livsfornægtende. Det siges f.eks. om titelpersonen i Sades roman "Juliette": "Juliette har videnskaben som credo" (D.d.A. p. 104) (9). Både Sade og Nietzsche begrunder den stærkes ret over for den svage med naturlovene og forkaster medlidenheden som gammelt borgerligt arvegods. Medlidenhed forudsætter, som Horkheimer og Adorno påpeger, fremmedgørelsen og forskellen mellem rig og fattig og tilslører kun for en tid denne tilstand. Sades kyniske syn på kærligheden og driftslivet udtrykker en bevidsthed om tingsliggørelsen af følelser og 
drifter, hvor kristendommens ærefrygt for kvinden derimod blot skal tildække en reel undertrykkelse.

Således bliver Sade og Nietzsche det borgerlige samfunds sande historieskrivere. Man kan med en grammatologisk omskrivning sige, at hvor Kant skaber den apologetiske skrift, der skal tildække (ideologisere) den bagvedliggende undertrykkelse, dér producerer Sade og Nietzsche den eksplicitte herre-skrift. Eller som Horkheimer og Adorno udtrykker det: "Idet den medlidenhedsløse lære forkynder identitet mellem magt og fornuft, er den barmhjertigere end borgerskabets moralske lakajers". (D.d.A. p. 127) (10).

Modstillingen Kant vs. Sade og Nietzsche er heller ikke primært historisk eller åndshistorisk motiveret, men skal tjene til belysning af en for forfatterne aktuel situation, det borgerlige samfunds relation til fascismen. Ligesom Kant tilslører den barske virkelighed i det borge rlige samfund, som Sade og Nietzsche blotlægger, så tilslører den borgerlige ideologi den brutale sandhed om samfundet, som finder sit sande udtryk i nazismen og antisemitismen. At nazismen er en logisk udvikling af den borgerlige kapitalisme og ikke dens modsætning, er den grundtese, hvorover Dialektik der Aufklärung er skrevet.

Denne påstand dokumenteres i afsnittet "Elemente des Antisemitismus" med den betydningsfulde undertitel "Grenzen der Aufklärung", hvorved nazismen udtrykkeligt sættes i relation til oplysningsbegrebet og den teknologiske fornuft. Menneskets herredømme over naturen skabtes som før nævnt på baggrund af en fortrængning af den menneskelige natur. Denne fortrængte natur eksisterede fortsat som en trussel og fandt undertiden en fortvivlet udvej i krig og aggression. Med nazismen sættes aggressionen for alvor i system.

Den natur, der slår ud i jødeforfølgelserne, er ikke identisk med den natur, mennesket på grund af oplysningen fjernede sig fra. Den er derimod selv fremmedgiort natur: "Hvor menneskeligt stræber efter at blive som natur, forhærder det sig samtidig mod den" (D.d.A. p. 189)(11). Den er en natur, der manipuleres med fra magthavernes side. Lystprincippet gives frit løb, samtidig med at det fra starten er underkastet realitetsprincippet. Over-jeg'et tvinger jeg'et til at projicere sine aggressionsdrifter ud i omverdenen. Horkheimer og Adorno bruger, som det fremgår af termerne, en freudiansk model.

Pointen $i$ analysen er, at det er jeg'ets had mod det selv, der af over-jeg'et kanaliseres mod jøderne. Den merneskelige utilfredshed under det liberale, kapitalistiske system er baggrunden for antisemitismen. Aggressionsdriftens retning skyldes, at de virkelige magthavere i produktionen er anonyme: "Den borgerlige antisemitisme har en specifik okonomisk baggrund: magtens forklædning som produktion." (D.a.A. p. 182)(12). Jøderne, der traditionelt er situeret $\mathrm{i}$ cirkulationsfæren (som vekselerere, 


\section{8}

købmænd etc.) er derimod synlige og kan derfor gøres til syndebukke.

Det sidste afsnit i "Elemente des Antisemitismus" er i modsætning til resten af bogen skrevet i 1947 , men adskiller sig ikke i grundsynspunktet fra de andre afsnit, men videreforer bogens idé om kapitalismens og fascismens identitet. Antisemitismen er aflost af den "demokratiske" valgfarce, som er arrangeret af storindustrien: "I stedet for den antisemitiske psykologi er i vidt omfang det blotte ja til den fascistiske stemmeseddel, inventaret for den stridbare storindustris paroler, trådt i stedet". (D.d.A. p. 210)(13). I liberalismens epoke var den menneskelige individuation nødvendig for at bringe det enkelte menneske på højde med produktivkræfterne. I dag dirigerer samfundsapparatet masserne gennem individuationen. Ligegyldigheden over for individet, der blot betragtes som en hindring for produktionen, findes overalt $i$ samfundet og $i$ videnskaben. Realitetsrettethed er ikke længere en dialektisk proces mellem subjekt og virkelighed, men et produkt fremstillet af industrien. Tingsliggørelsen er $\mathrm{i}$ samfundet så vidt fremskreden, at en forestilling om sandheden straks vil blive afvist som utopi og sekterisme.

Hvor mennesket $\mathrm{i}$ det vestlige samfund om dagen er offer for en fremmedgørende arbejdsproces, indfanges det $i$ sin fritid af kulturindustrien, der fungerer som samfundets forlængede arm med sin cirkel af manipulation og tilbagevirkende behov: "Uvægerligt reproducerer hver enkelt manifestation i kulturindustrien mennesket som det, helheden har giort det til"'. (D.d.A. p. 135)(14). Kulturindustrien er styret af markedsmekanismen og fungerer som reklame for storindustrien. Overalt reproducerer den den herskende ideologi og forhindrer kritisk tænkning ved en systematisk forarmelse af det menneskelige sprog og begrebsapparat. Gennem sin realisme bilder den konsumenterne ind, at den givne eksistens er den eneste mulige. Kulturindustrien bygger pả en bestemt model: "den falske identitet mellem det almene og det individuelle", (D.d.A. p. 128)(15), d.v.s. at den gennem sine produkter postulerer at skildre det menneskeligt almene, mens den i virkeligheden fastholder et falsk, stivnet menneskebegreb.

Den postulerede forsoning mellem alment og individuelt resulterer $i$ stilmæssigt harmoniske, strømlinede produkter. Som disses modsætning står de store kunstværker, der i bruddet mellem stil og indhold artikulerer de lidelser, som samfundet forårsager, men prøver at tildække: "De store kunstnere var aldrig dem, hvis stil manifesterede sig mest fuldkomment og uden brud, men derimod dem, der $\mathrm{i}$ værket satte stilen op som hårdhed mod det kaotiske udtryk af lidelse, som nagativ sandhed". (D.d.A. p. 138)(16). Kunsten bliver således for Horkheimer og Adorno et reservat for den undertrykte protest mod samfundet, men samtidig er det samfundet, der har tildelt kunstens dens område og dermed udelukket den fra nogen indflydelse på samfundets indretning. Kunsten vil derfor altid artikulere en 
protest og derigennem udtrykke det sande almene, men denne protest vil forblive virkningsløs, fordi den fungerer på det borgerlige samfunds præmisser: "Den borgerlige kunsts renhed, der som frihedens rige stiller sig i modsætning til den materielle praksis, var fra begyndelsen af købt med udelukkelsen af underklassen, hvis sag, den rigtige almenhed, kunsten netop gennem frigørelsen fra den falske almenheds mål, forbliver tro". (D.d.A. p. 143)(17). Kunsten relateres altså til underklassens (= proletariatets) sag, så vidt denne er hele menneskehedens, men forbliver alligevel borgerlig kunst, fordi den fungerer inden for det arbejdsdelte samfund og på dets præmisser.

Som illustration til kunstens placering inden for det borgerlige samfund, anvender Horkheimer og Adorno fortællingen om Odysseus og sirenerne. (Odysseén er som næunt i denne fortolkning myten om den borgerlige fornufts fødsel). Da Odysseus passerer sirenernes $\emptyset$, befaler han sine mænd at stoppe vat $\mathrm{i}$ orene, mens han selv undlader dette for i stedet at lade sig binde til skibets mast. Derved opnår han at høre sirenernes vidunderlige sang uden at løbe risikoen for at falde for fristelsen til at blive på deres $\emptyset$.

Sirenerne repræsenterer her det lystprincip, som kunsten rummer i sin opposition til samfundet og dets realitetsprincip. Odysseus nægter ved sin vægring at følge lystprincippet. Derved reduceres den kunst, sirenerne repræsenterer, til blot sanselig pirring og mister derved muligheden for at øve indflydelse på dannelsen af det borgerlige jeg: 'Så længe kunsten renoncerer på at gælde som erkendelse og derigennem udelukker sig selv fra praksis, tolereres den af den samfundsmassige praksis som lyst". (D.d.A. p. 39) (18). Hvor sirenernes sang i Odysseen endnu repræsenterer en reel fristelse, har kunsten i det moderne "oplyste" samfund, ganske tabt sin mulighed som praksis.

Videnskabsteoretisk set vender Horkheimer og Adorno sig altså mod den empiristiske eller positivistiske holdning, som ved at sætte naturvidenskaberne, matematikken og den formaliserede logik som mål for den samlede videnskab har tjent undertrykkelsen, ja endog skabt den. Den borgerlige, idealistiske filosofi (Kant) forkastes, fordi den prøver at tildække de reelle, materielle forhold.

Hegels terminologi anvendes spredt (f.eks. i brugen af termerne det individuelle og det almene), men den generelle optimistiske tendens, iflg. hvilken mennesket bevæget sig mod større og større selvforståelse, forkastes utvetydigt. Man finder også flere af Marx' nøgleord: tingsliggørelse, brugs- og bytteværdi, som dog mere leder tankerne hen på den unge humanistiske Marx, end på den ældre og hans konkrete analyse af den borgerlige økonomi. Denne skepsis over for marxismen som filosofisk system skyldes dels dens anvendelse til undertrykkelse af det russiske folk (19), dels forfatternes skepsis over for muligheden af klassekamp i det vestlige samfund. De fornægter ikke den reelle undertrykkelse af arbejder- 
klassen, men mener, at denne gennem bevidsthedsmanipulationen for stedse er integreret $i$ det kapitalistiske samfund.

Freud er nok den tænker, der har haft størst indflydelse på Dialektik der Aufklärung. Det ses både i den psykoanalytiske studie af antisemitismen, og i bogens generelle påvisning af undertrýkkelsen af naturen og lystprincippet $\mathbf{i}$ den borgerlige verden.

Mens Freud således kan anvendes til en artikulation af samfundets onde, kan han lige så lidt som de andre tænkere pege på en løsning af problematikken. Horkheimer og Adorno tegner et billede af et samfund, der mere og mere lukker sig om sig selv, og som med den fuldstændige bevidsthedsstyring af samfundsindividerne er i stand til at dæmme op for ethvert oprørsforsøg. Den teknologiske fornuft, der i virkeligheden er totalt irrationel, gennemtrænger săledes alle samfundets niveauer.

Mod denne tilstand kan filosofien ikke monstre et alternativt system, fordi den abstrakte, systematiske tænkning netop er ondets rod: "Den [filosofien] anerkender ingen abstrakte normer eller mảl, som ville kunne anvendes i modsætning til de gældende" (D.d.A. p. 260) (20). Filosofien må derimod over for samfundets suggestion fastholde sandheden og friheden. Dens asketiske opgave bliver at låne sit sprog til modsigelsen mellem det samfundet siger, og virkeligheden.

Denne pessimistiske holdning over for filosofiens og videnskabens muligheder fastholder Adorno i alle sine senere skrifter. Han skriver således i sit opgør med den sociologiske, empiriske forskning i artiklen "Sosiologi og empirisk forskning fra 1957: "Forhåndspregningen av befolkningens bevissthet tiltar nemlig i takt med den fremadskridende kommunikative innfangning av befolkningen i så stor grad at det knapt lenger er et hull som ville tillate at man uten videre fikk rede på denne forhåndspregning" (21).

I forordet den lille analysesamling "Eingriffe. Neun kritische Modelle" fra 1962 karakteriserer Adorno den historiske situation med ordene: "[...] men et historisk øjeblik, hvor al slags praksis, som er rettet mod helheden, synes udelukket [...]. Der går her en lige linje frem til Adornos hyppige, men upræcise tale om den forvaltede verden i den æstetiske teori.

Adornos filosofiske standpunkt ændrer sig heller ikke fundamentalt, men bevæger sig dog mod en mere eksplicit venstre-hegeliansk holdning. I den lille væsentlige artikel "Wozu noch Philosophie" fra Eingriffe angriber Adorno flere af tidens forskellige filosofiske stromninger. Kritikken af positivismen er en gentagelse af argumenterne fra Dialektik der Aufklärung, mens polemikken mod fænomenologiens (specielt Heideggers) Værensontologi er ny. Begge de angrebne retninger har metafysikken som fjende, men ender i apologi for det bestående. I dem forsvinder fornuftens autonomi og hermed også friheden og samfundets mulighed for selvbestemmelse. 
Positivismens fejl er, at den ureflekteret anerkender det bestående samfundsmæssige udgangspunkt og dermed arbejdsdelingen, hvorved den uvilkårligt afspejler en tingsliggiort bevidsthed.

Heideggers kritik af den vestlige, filosofiske tradition og dens adskillelse af det værende (fænomenerne) og begrebet fører han til en påstand om en ontologisk Væren (Sein). Men dette begreb er iflg. Adorno også udtryk for en tingsliggiort bevidsthed, idet den i sin tro på Værens umiddelbarhed fornægter altings formidlede karakter og dermed betydningen af den menneskelige praksis. Dens politiske konsekvens er, hævder Adorno, fascismen: "Heideggers indordning i Hitlers forerstat var ingen opportunistisk handling, men en logisk folge af en filosofi der identificerede Væren og fører”. (Eingriffe p. 17)(22).

Marxismen er i Osteuropa stivnet til dogmatisk ideologi og er selv blevet et abstrakt system, der undertrykker det individuelle. Den dialektiske filosofi, Adorno forestiller sig, tænker ikke som Marx i klassemodsætninger, men $i$ abstrakt helhed og negation. Praksis relateres til en filosofi, der negerer den samfundsmæssige totalitet: "Den praksis, der har fremstillingen af en fornuftig og myndig menneskehed som sit mål, forbliver uden virkning uden en teori, som tænker helheden i dens usandhed". (Eingriffe p. 24) (23).

Her vender Adorno tilbage til Hegel, ikke den Hegel, som i sin retsfilosofi skrev preusserstatens apologi, men den dialektiker, der ser åndens udvikling som en stadig erkendelsesmæssig korrektion af forholdet mellem det værende og dets begreb. Da det værende i dag er usandt som totalitet, må den filosofi, der vil korrigere det, blive rent negativ og dermed en bevidst funktionsløs tænkning: "Kun en tænkning, som uden mentalt reservat og uden illusion om sit indre kongedømme indrømmer sin egen afmagt, kaster måske et blik ind i det muliges, det ikke-værendes orden, hvor menneskene og tingene ville være på deres rette plads". (Eingriffe $\mathrm{p}$. 26) (24). Kun gennem konfrontationen af samfundets falskhed med begreberne frihed og sandhed har fisolofien en mulig værdi.

\section{Den fragmentariske form}

Adornos opposition mod en systematisk filosofi får også konsekvnenser for formen i hans værker. "Dialektik der Aufklärung" har således undertitlen "Philosophische Fragmente", der netop understreger bogens antisystematiske sigte. Den munder således ud i en lang række aforisme-agtige optegnelser og udkast. Den æstetiske teori er selvfølgelig ikke er færdigt værk fra forfatterens side, men man kan alligevel også her konstatere en antisystematisk tendens. Udgiverne henviser $i$ deres efterord til et brev fra Adorno, hvori han erklærer, at der filosofisk intet oprindeligt 
142

gives, og at man derfor ikke kan opbygge en traditionel trinvis argumentationssammenhæng, men at man må fremstille det hele koncentrisk som havende samme vægt. En sådan konstruktionsmåde kaldes af Adorno parataktisk (25).

Sine litteraturessays benævner Adorno eufemistisk "noter til litteratur". I forste binds forste essay behandler han "Der Essay als Form", hvor han forklarer sin forkærlighed for den korte, causerende form. Essayet er antisystematisk og en protest mod det teoretisk uholdbare og i virkeligheden tyranniske, videnskabelige krav om fuldstændighed og kontinuitet i tankeprocessen. Essayet rummer derfor en utopisk intention i sin antinomi til den abstrakte, systematiske tænkning og bliver derfor en kritisk, ja en ideologikritisk form: "Det [essayet] er, hvad det var fra begyndelsen, den kritiske form par excellence; og som immanent kritik af åndelige frembringelser, som konfrontation af hvad de er med deres begreb, ideologikritik". (Noten zu Literatur I p. 39 (fremover N.z.L.)) (26). Essayets inderste formlov er kætteriet. Det anerkender intet som umiddelbart som f.eks. både positivismen og ontologien, men peger på altings formidlede karakter. Herved bliver det $\mathrm{i}$ stand til at distancere sig fra de herskende tilstande.

Essayet henter sin kraft fra sin sproglige opbygning. Takket være sit slægtskab med retorikken kan essayet besidde et subjektivt udtryk og en musikalsk logik, der kan sættes op mod den videnskabelige diskursive logik. Essayet er heri beslægtet med kunsten. (Den potitentielle befriende kraft, som det kunstneriske sprog ejer, er et af Adornos væsentligste temaer, som vil blive behandlet senere $\mathrm{i}$ forbindelse med hans æstetiske teori og litteraturkritiske praksis).

\section{Estetikkens plads $i$ den kritiske teori}

Horkheimers og Adornos opfattelse af kunstens placering inden for den borgerlige samfundstotalitet som et område, hvor mennesket kan give sin lidelse form og derved protestere mod de herskende tilstandes umenneskelighed, samtidig med at det er det samme samfund, der har anvist kunsten dens rolle inden for arbejdsdelingen og dermed giort den harmløs, videreføres med en fantastisk konsekvens af Adorno i hans æstetiske teori og hans litterære essays. Kunsten er på én gang en protest mod borgerligheden og borgerlig kunst.

Kunsten tænkes hos Adorno altid i forbindelse med samfundet. Den æstetiske teori skal derfor ses i relation til Adornos kritiske samfundsteori, uden at der derfor er tale om identitet. Estetikken har i det nuværende samfund sit definerede autonome område, som må forstås immanent, samtidig med at det skal integreres i en forståelse af samfundstotaliteten. Den overskuende, kontemplative holdning, der indordner æstetikken i et 
filosofisk system og dermed giver filosofien magt over kunsten som hos Kant og Hegel er ikke længere mulig. I en tid, hvor filosofien er blevet undertrykkelsesinstrument, får kunsten kun mening ved at sige fra over for filosofien. Filosofien er blevet en apologi for det bestảende, det empiriske, mens kunstens sandhedsindhold ligger $i$ dens afstandstagen fra empirien: "Produktiv var æstetikken kun så længe den fuldstændigt accepterede distancen fra empirien". (Frühe Einleitung. Ästhetische Theorie p. 497. Fremover A.T.)(27).

Det betyder ikke, at den æstetiske teori skal være begrebsløs og irrationel, i så fald vil den blive vare i det borgerlige samfund, der dyrker kunstens autonomi. Den skal hverken konstrueres ud fra begreber eller ud fra det begrebsløse, men reflektere det formidlede forhold mellem faktum (kunsten) og dets begreb. Teorien må derfor ikke blive et filosofisk system, der udefra trykkes ned over det æstetiske objekt, men den må respektere og gå ind i værkets immanens. En sådan æstetik vil ikke blive værdifri, men vil i sit forsøg på at reflektere det sande og det falske i det æstetiske objekt blive kritisk. Kunstfilosofiens opgave bliver at erkende det potentielt subversive element $\mathrm{i}$ kunsten, d.v.s. at forstå det, der ud fra de givne samfundsmæssige begreber er uforståeligt. Den vil dermed afdække det, samfundet fortrænger.

Samtidig med at kunsten protesterer mod samfundet, er den dog også et samfundsmæssigt produkt. Ved at fastholde begge disse momenter i kunsten bliver den æstetiske teori historisk og dialektisk, og gennem den immanente analyse udledes det historiske indhold, ikke ved at abstrahere det fra formen, men ved at gribe det gennem forståelsen af nødvendigheden af den specifikke kunstneriske form.

Den tvetydighed, Adorno tillægger kunsten, hænger sammen med den entydighed, han tillægger samfundet. Samfundets undertrykkelse og magt opfattes som total over for de magtesløse individer. Han siger således $i$ Asthetische Theorie: "I den forvaltede verden er neutraliseringen universel". (А.T. p. 339) (29). Konsekvensen af den æstetiske autonomi er kunstens neutralisering. Hvis kunsten sigter på samfundsrettet praksis, hvis den vil være engageret, så forskriver den sig til den rationelle, målrettede tænkning, der netop er samfundets. Kun som funktionsløs kan kunsten blive et billede på et samfund, der ikke længere dirigeres af nytteprincippet og egoistiske, materielle interesser. Det er som sådan, den modernistiske kunst manifesterer sig midt $i$ den forvaltede verden, og det er som dennes æstetiske filosof, at Adorno træder frem.

\section{Adornos forhold til den traditionelle cestetik}

Der er ingen tvivl om, at æstetikeren Adorno meget bevidst indskriver sig $\mathrm{i}$ den tyske, idealistiske tradition, der har Schiller, Kant og Hegel som 


\section{4}

hovedmænd, samtidig med at han på afgørende punkter tager afstand fra den. Hos Kant er der en modsigelse mellem den ydre verden, som er underkastet naturlovene, og den indre menneskelige frihed. Denne kløft heles ved hjælp af det sublime og det skønne, repræsenteret af naturoplevelsen og kunsten. Fantasien forsoner således det indre og det ydre, sanserne og fornuften. For Schiller forenes i kunsten forminstinkt (Formtrieb) og materialeinstinkt (Stoftrieb) gennem kunstens legeinstinkt (Spieltrieb) (30). Kunsten manifesterer lystprincippet og skaber ud af en splittet social tilværelse en harmonisk helhed. På samme måde er kunsten hos Hegel sanseliggiort idé; den forener den empiriske eksistens med ånden på et bestemt trin i verdensåndens udvikling.

Ligesom Lukács afviser den ideologiske tendens i forsøget på gennem kunsten at bygge bro over samfundets modsætninger og dermed tilsløre dem, afviser Adorno den idealistiske filosofi og æstetik (32). Kant roses for som den første at have erkendt, at den æstetiske modtagelse adskiller sig fra den umiddelbare praktiske, dagligdags erkendelse. Kunsten vækker hos Kant "det interesseløse behag". Herved har han frigjort æstetikken fra den traditionelle virkningsæestetik og påpeget kunstens autonomi. Fejlen hos Kant er imidlertid, at han helt tager kunsten ud af historien. Năr han i "Kritik der Urteilskraft" definerer det skønne som "Det der behager alment uden begreb". (33), så gør han en historisk specifik smag til en generel menneskelig og glemmer, at det almene velbehag, som kunsten efter hans mening vækker, hænger sammen med samfundskonventioner. Kant når iflg. Adorno frem til æstetikkens objektivitet ligesom til etikkens gennem formalisering og abstraktion. Herved forbryder han sig mod kunstens væsen, som er det individuelle.

Adornos forhold til Hegels æstetik er som omtalt yderst komplekst. Her skal blot skitseres en generel holdning. Nogle af de væsentligste begrebspar i Adornos dialektiske tankegang: det almene og det individuelle, modsætningen mellem "Geist" (bevidsthedsform) og empiri, det naturskønne og det kunstskønne, er begreber fra den hegelianske filosofi. De anvendes imidlertid ikke i Hegels idealistiske tradition, men forsøges brugt inden for en materialistisk teori.

For Hegel er det skønne lig ideens sanselige tilsynekomst. Den er et stadium i den absolutte ånds udvikling (34) og således en station på vejen mod menneskets absolutte erkendelse. Hegels tankegang forudsætter altså en vis identitet mellem det specielle og det almene, mellem subjekt og objekt, mellem kunst og virkelighed. Herved gøres kunsten til de herskende ideers medsammensvorne, og Hegels æstetik ender som hans filosofi i en apologi for det bestående. Hegel skabte dialektikken, men ud fra en rent ideologisk opfattelse af historien: "Har hans [Hegels] begreb lykkeligt formidlet historien med sandheden, så er til gengæld dets egen sandhed ikke til at isolere fra det ulykkelige i historien". (A.T. p. 523) (35). For 
Hegel er kunsten ren ånd, for Adorno er ånden kun et moment i den.

For Hegel er kunsten kun det forste led $\mathrm{i}$ den absolutte ands selvudvikling, som senere vil blive fortsat af religionen og filosofien. At Hegel forudså kunstens død skyldtes, at den absolutte ånd efter hans mening nærmede sig sin egen fuldkommengørelse, hvor væren og begreb ville være identiske. Da kunsten altså ikke er den sidste fase i denne udvikling, er der altså ikke fuldstændig identitet mellem den og sand virkelighed. Det er denne lille afstand, Adorno uddyber.

Adorno kan også i teorien forudse et samfund uden kunst. Det vil være et samfund, der har realiseret de utopiske intentioner, der ligger i kunsten. I praksis ser Adorno imidlertid ingen muligheder for at dette idealsamfund vil blive skabt, og derfor vil kunsten stadig have den funktion at give stemme til den lidende bevidsthed.

Det er $\mathrm{i}$ brugen af begrebsparret det individuelle og det almene, at oppositionen mellem Hegel og Adorno tydeligst aflæeses. For Hegel udtrykker kunsten en, om ikke fulstændig, så dog delvis identitet mellem det individuelle og det almene, ånden, som er tidens ånd. For Adorno eksisterer der to former for almenhed. Det almene, der er lig den herskende tankegang (tidsånden) er en falsk almenhed, som tilslører reelle modsætninger. Mod dette falske almene sætter kunsten sin individualitet for gennem negationen af det bestående at åbne vejen for en mulig realisation af det sande almene.

Adorno kalder et sted sin æstetik for materialistisk-dialektisk ( 12). Den er materialistisk i den forstand, at æstetikken ikke opfattes som åndens værk uden for eller i den konkrete historie, men som et samfundsmæssigt produkt, og dialektisk $i$, at den både sammentænker kunsten og samfundet og fremhæver kunstens eget specifikke niveau i forholdet til den empiriske eksistens. Marxistisk kan Adornos teori derimod ikke siges at være, idet kunsten ikke bringes i relation til noget klassebegreb. Derimod fremhæver Adorno kunstens potentielt revolutionære holdning i forhold til et alment menneskebegreb. Der er her ligesom i Dialektik der Aufklärung tale om et slægtskab mellem Adorno og den unge Marx' antropologi. Mod den traditionelle, marxistiske æstetik, personificeret i den ældre Lukács, polemiserer Adorno derimod skarpt og beskylder den for at være borgerlig og udialektisk (36).

Bag Adornos antropologi ligger som påvist også Freuds psykoanalytiske model og hans skitse til en kulturfilosofi. Derimod er Adorno skeptisk indstillet over for den psykoanalytiske kunstteori, der of te repræsenterer et tilbageskridt $\mathrm{i}$ forhold til Freuds egne tanker. Den psykoanalytiske fortolkning reducerer kunstneren til neurotiker og knæsætter hermed det herskende normalitetsbegreb som norm. Den driver, som Adorno siger, kultus med realitetsprincippet (37).

Kunstværkerne bliver for psykoanalytikeren blotte dagdromme, hvor- 
146

ved kunstens formelement negligeres, og kunsten reduceres til sit stof. Dette er et tilbageskridt $i$ forhold til Freud selv, der lagde vægt på drømmens arbejde (38). Den psykoanalytiske kunstteoris billede af kunstneren som neurotiker er også reaktionært, fordi det reducerer kunsten til et individuelt spørgsmål og derved fratager kunsten dens almene, historiske betydning. Kunsten er ikke blot en flugt fra virkeligheden, men også en dom over den virkelighed, der flygtes fra. Gennem den psykoanalytiske fortolkning mister kunsten sin sandhedsværdi: "Gøres den opnåede sublimering og integration til kunstværkets ét og alt, så taber det den kraft hvorigennem det overstiger tilværelsen, fra hvilken det siger sig fri gennem sin blotte eksistens". (đ̈.T., p. 25) (39).

\section{Kunstens autonomi og samfundet}

Det er for Adorno en kendsgerning, at kunsten i det arbejdsdelte samfund fungerer på dettes præmisser, og at den derfor, når den tenderer mod at glemme sin plads for at tale umiddelbart, som havde den magt til at ændre disse forhold, bliver ideologisk. Kunstneren må erkende kunstens specielle rolle og dens relative autonomi, forst da bliver kunsten paradoksalt nok "fait social". Det samfundsmæssige i kunsten ligger ikke i dens umiddelbare produktionsmåde, ej heller i dens historiske stofindhold, men i det, hvorfra kunsten adskiller sig fra samfundet. Her bliver den kunstneriske form den centrale kategori, fordi formen radikalt omstrukturerer elementerne fra empirien: "Form virker som en magnet, der ordner elementerne fra empirien på en måde så de gøres fremmed for den sammenhæng de havde $\mathrm{i}$ den transæstetiske eksistens, og kun derigennem kan de indgå forhold med den transæstetiske essens". (đ.T., pr. 336) (40).

Mens kulturindistrien ukritisk gengiver den empiriske eksistens, distancerer kunsten sig gennem formen fra den og bliver derved i stand til at artikulere en protest imod den. Det vil sige, at et kunstværks historiske aktualitet ikke afhænger af det umiddelbare indhold, men af det indhold, som taler ud gennem formstrukturen. Kafkas værker, hvor monopolkapitalismen og den forvaltede verden kun sjældent kommer direkte til syne, er på grund af deres form og sproglige saglighed mere samfundskritiske end romaner om korrupte industriforetagender (41). De er sande, fordi de sprogligt afbilder den samfundsmæssige tingsliggørelse og derved negativt artikulerer en protest mod den.

Adornos kunstopfattelser er en dialektisk linedans midt mellem to modsatte krav, der traditionelt stilles til kunsten. Fra den ene side lyder kravet om engageret litteratur, fra den anden nævnes kunstens autonomi. Begge standpunkter forkastes af Adorno. Begrebet engageret kunst er en selvmodsigelse, fordi kunstens vasen netop ligger i dens distance til virkeligheden. Autonom kunst på den anden side fornægter den sociale virkelighed, der er den aprioriske forudsætning, som kunsten definerer sig negativt ud fra. 
Engagement i kunsten sættes af Adorno højere end tendens. Engagementet udtrykker et højere refleksionsniveau end tendensen. Hvor den tendentielle kunst sigter mod partielle reformændringer, stræber den engagerede mod en ændring af de fundamentale betingelser. Sidstnævnte er altså mere radikal end tendenskunsten.

I essayet: "Engagement" (Noten zur Literatur III) polemiserer Adorno mod den engagerede kunst, personificeret i Sartre og Brecht. Sartres fejl er, at han udelukkende opfatter kunsten, in casu litteraturen, som kommunikativt sprog og derved fornægter dens udtryksværdi. Herved reduceres kunsten til et spørgsmål om kunstnerens intention, hvorved kunstens objektivitet, dens forhold til den historiske situation, undertrykkes. Estetisk set medfører Sartres synspunkt, fordi hans kunst stræber mod realisme, en reaktionær form. Det siges om hans stykker: "Sartres stykker er som midler for det forfatteren vil sige blevet passeret af udviklingen i de æstetiske former". (N.z.L. III, p. 116) (42). I kravet om realisme mødes Sartre med den sorteste reaktion.

Sartres fundamentale fejl er, at han ikke analyserer den historiske situation. Sartres krav om engagement forudsætter en subjektiv frihed, som objektivt, d.v.s. historisk, ikke længere eksisterer. Han underkender det objektives betydning og forbliver derfor udialektisk. Sartres negligering af de objektive tilstande, konstaterer Adorno sarkastisk, gav ham succes og integrerede ham i kulturindustrien. Den engagerede kunst bliver reaktionær, fordi alle kan slutte op bag den: "Når endog folkemord i den engagerede litteratur bliver til kulturel ejendom, så bliver det lettere at spille med i den kultur, der fødte mordet". (N.z.L. III, p. 127) (43).

Brecht postulerer i modsæetning til Sartre ikke individets suverænitet, men ser det marxistisk som formidlet gennem samfundets klasser. Derfor opponerer han mod den kunst, der centreres om den æstetiske individuation, og skaber sin egen dramatik baseret på "Verfremdungs-"effekten. Dramatikkens sigte er her at skildre kapitalismens væsen.

Brechts teater hviler på simplifikationsprincippet, hvis mål er at fremstille en yderst kompliceret, politisk problematik på en måde, så tilskueren kan forstå den og derefter om muligt gå over til revolutionær handling. Denne simplifikation bliver for Adorno en forfalskning, fordi Brecht $i$ sine politiske stykker forenkler sagen og derved undervurderer modstanderen. Målt på sine egne politiske præmisser er Brechts teater falsk og ideologisk, fordi den foregøgler tilskueren, at modstanderne er idioter og lette at besejre. I "Arturo Ui" skildres Hitler og hans slæng f.eks. som udbyttende grønthandlere og bliver derfor harmløse. I "Mutter Courage" bruges 30 års-krigen til at skildre noget nutidigt, hvilket er både æstetisk og politisk forkert. Simplifikationens konsekvens finder Adorno i Brechts delvise opbakning bag Stalin.

Den engagerede litteraturs æstetiske fejltrin skyldes såvel hos Sartre 
148

som hos Brecht en forkert vurdering af den objektive, historiske situation. Det sande kunstneriske udtryk for denne finder Adorno i Kafkas og Becketts digtning, der skildrer "det menneskelige subjekts demission". I sin troskab mod beskrivelsen af det konkrete, at mennesket ikke længere er herre over sin egen tilværelse, udtrykker denne kunst den eneste mulige protest: "Det skal være anderledes". (N.z.L. p. 134) (44). Som rene kunstværker peger de pà den praksis, de selv afholder sig fra, på fremstillingen af det rette liv.

Adornos udgangspunkt er her igen det arbejdsdelte samfund, hvor kunstværkets mulighed for politisk indgriben er lig nul. At Beaumarchais' komedier havde en vis effekt, var mere afhængig af den historiske situation end af værkerne selv. I dag er situationen en anden. Brechts stykker bliver blot forstået af de i forvejen frelste (45). Politisk praksis er altid en form for magtmisbrug, mens kunsten, selv den mest aggressive, står magtesløs. Det skyldes først og fremmest, at kunsten opponerer mod det kommunikative sprog, som behersker samfundet. Hvor den selv bliver kommunikativ, som $i$ den engagerede kunst, neutraliseres den straks og optages i den borgerlige bevidsthed.

\section{Det almene og det individuelle}

Begreberne det almene og det individuelle hører som nænvt hjemme i den Hegelske filosofi og æstetik. De udtrykker det forhold, at det individuelle kunstværk definerer sig selv $i$ forhold til en bestemt almen, historisk situation. Hegels fejl, som var en konsekvens af den idealistiske filosofi, var, at han identificerede kunsten med ideen: "Idealismens emfatiske idébegreb relegerer kunstværkerne til eksempler på den altid samme idé". (A.T. p. 194) (46). Hegels begreb om ideen eller ånden svarer til den herskende bevidsthedsform. Der forudsættes altså identitet mellem kunsten og samfundets bevidsthed.

Mod dette hævder Adorno som bekendt kunstens relative autonomi og dens immanente protest mod samfundet og de herskende tanker. Adorno spalter her begrebet det almene. Den almenhed, samfundet og ideologien taler om, er den dårlige almenhed, som i virkeligheden er partikulær, fordi den bygger på en klasses undertrykkelse. Her overfor sætter kunsten en individualitet ind, som forholder sig til det sande almene. Dette er den frie, menneskelige tilstand, der endnu ikke er realiseret, men som kunstværker lader ane muligheden af.

Adorno kommer ind på problemet i "Rede über Lyrik und Gesellschaft" (N.z.L. I), hvor lyrikken placeres i forhold til de nævnte begreber. Et digt siges her i kraft af sin æstetiske udformning at være delagtig i det almene. Dets almenhed er imidlertid ingen "volenté de tous", ikke det de fremmedgiorte mennesker tror er det almene, men som blot er den 
herskende slette almenhed. Det er derimod en sand almenhed, som kun opnås gennem digtets kompromiløse individuation: "Gennem den ubegrænsede individuation håber det lyriske billede at nå det almene". (N.z.L. p. 75( (47). Digtet artikulerer drømmen om en verden, som er anderledes. Hvad Adorno her siger om lyrikken, viser den æstetiske teori er generelt for kunstens væsen. Blot udtrykker lyrikken måske i sin korte form og $\mathrm{i}$ sin afstandtagen fra det kommunikative sprog kunstens utopiske intention endnu tydeligere.

Mens den diskursive tænkning i dag gennem en falsk postuleret objektivitet tilintetgør det subjektive, fastholder kunsten det subjektive for at nå frem til en sand objektivitet. Kunsten artikulerer den individuelle modstand mod den repressive kollektivisme og peger derved $i$ sin ensomhed mod en ny, menneskelig tilstand. Derved bliver kunsten ikke harmonisk i klassisk forstand, hvor harmonien var et resultat af undertryk. kelse af det individuelle, men udtrykker gennem disharmoni og brudflader negativt drømmen om en ægte kollektiv almenhed.

\section{Kunsten og ideologien; kunsten som fetisch}

I det foregående har jeg lagt vægten på, hvorledes kunsten iflg. Adorno overskrider den herskende ideologi. Dette skal ikke tilsløre, at kunsten også er ideologisk, og det allerede i sit udgangspunkt. Kunsten eksisterer på det arbejdsdelte samfunds præmisser og anerkender derfor à priori den ulykkelige adskillelse af åndelig og materiel produktion: "Formelt er de [kunstværkerne] uafhængigt af det de siger, ideologi ved à priori at sætte det ândelige som noget af betingelserne for den materielle produktion uafhængigt og derfor højere rangerende og ved at tilsløre den urgamle skyld $\mathrm{i}$ adskillelsen af kropsligt og åndeligt arbejde". (đ̈.T.) p. 337.

Ved at indgå $i$ varecirkulationen og at anerkende samfundets bytteprincip bliver kunstværket til fetisch i den borgerlige samfundsøkonomi. Men gennem sin totale nyttesløshed i forhold til en kortsigtet, samfundsrets praksis distancerer der sig fra den herskende varefetischisme. Ved sin nyttesløshed bliver den billede på et befriet samfund hinsides nytteprincip. pet.

Kunstens utopiske figur er således en konstellation af det værende og det ikke-værende, af ideologi og sandhed. Kunsten kan, selv i sin mest radikale skikkelse, synes kynisk, fordi den på randen af en truende verdenskatastrofe hæuder en åndelig og kulturel eksistensberettigelse, samtidig med at den fastholder bevidstheden om både sin afmagt og sin delvise medskyldighed. Det paradoks, Adorno klynger sig til, er, at kunsten både er borgerlig kunst, d.v.s. medskyldig i dette samfunds forbrydelser, og ant $i$-borgerlig i sin artikulation af drømmen om en bedre fremtid. Kunstens utopiske funktion kan derfor ikke tænkes marxistisk i forhold til en klasse, men kun i forhold til et almentmenneskeligt "vi". 
Adorno vender sig mod den borgerlige ideologi, samtidig med at han, som Jørgen K. Bukdahl fremhæver, kritiserer ideologikritikken og dens nuværende repressive funktion, hvor den fornægter ideologiens sandhed og derved blot konservativt bekræfter sig selv (49). En sådan tendens aflæser Adorno i østlandenes marxistiske æstetik, personificeret i den ældre Lukács, hvor ideologikritikken tjener undertrykkelsen.

Til de unge aktivister i Tyskland, der i dag vil afskaffe kunsten, siger Adorno, at det er en illusion at tro, at samfundet i dag kan forandres. De personer, der $i$ et samfund på vej mod det totale barbari, vil afskaffe kunsten, gør sig til dette samfunds medskyldige. At mảle kunsten som nødvendighed, d.v.s. i forhold til dens umiddelbare nytte, er at overføre bytteprincippet som målestok på den, og det er iflg. Adorno identisk med at anerkende den herskende, undertrykkende tankegang. Kun der, hvor ånden overlever, d.v.s. i kunsten, eksisterer endnu en mulighed for modstand mod den samfundsmæssige totalitet.

At kunstnerens intention og værkets objektive indhold er to forskellige ting for Adorno, bliver af betydning i forholdet mellem kunst og ideologi. Ligesom en engageret kunstner som f.eks. Sartre på grund af sin poetik nødvendigvis må skrive kunst, der integreres i den borgerlige verden, kan reaktionære digtere skabe progressive værker, fordi historien og samfundet indskriver sig i dem på tværs af personlige synspunkter. Således påviser Adorno f.eks. progressive elementer hos de store, tyske lyrikere Eichendorff, Hölderlin og George og hos franskmanden Valéry som trædende frem i deres kunstværker til trods for forfatternes ande tsteds ekspliciterede reaktionære, politiske holdning.

Her er Adorno imidlertid yderst uklar. Det er også muligt at læse ham på den måde, at de næunte digtere netop er progressive, fordi de er reaktionære. De udtrykker i protest mod en frembrusende, tingsliggiort, borgerlig verden en længsel tilbage mod en svunden tids autentiske værdier. Den rigtige fortolkning er sikkert, at værdien i deres kunst ligger i den negerende operation i forhold til samfundet, mens den positive sætten af værdier i fortiden selv er ideologisk. Gennem negationen frigøres kunsten fra det individuelt tilsigtede og får derved en objektiv, historisk betydning.

\section{Det skønne og det hoeslige i kunsten}

Adornos æstetik er et opgør med den klassicistiske opfattelse af kunsten som harmonisk og skøn og et forsøg på at reflektere modernismens opgør med skønhedsdyrkelsen. Klassicismens krav om skønhed byggede på en fortrængning af væsentlige sider af den sociale virkelighed, og harmoniæstetikken grundedes reelt på vold over for det anderledes-værende. Hvis noget hæsligt blev optaget $\mathrm{i}$ et kunstværk, blev det neutraliseret og assimileret i det skønne. Dette var imidlertid en falsk forsoning. 
At begrebet det skønne således problematiseres, betyder ikke at Adorno opgiver det, men at han prøver at tænke det $\mathrm{i}$ en moderne social og æstetisk sammenhæng. I den modernistiske kunst dukker det hæslige op og integreres ikke. Det bryder med sin dissonans bevidst kunstværkets helhed. Den moderne kunst fastholder det hæslige for at undgå den falske forsoning med verdenen. Herigennem bliver kunsten vidne for det $\mathrm{i}$ kulturen fortrængte og en protest mod samfundets vold. De store kunstværker beholder i deres materiale noget hæsligt og uassimileret.

I et moderne kunstværk indgår det skonne og det hæslige en dialektisk forbindelse. Kunsten prøver gennem formen indirekte at skildre skønheden hinsides det bestående, samtidig med at det hæslige erindrer om det nuværendes undertrykkende tvang: "Det frygtelige ser ud fra skønheden selv som den tvang, der stråler ud fra formen" (A.T. p. 83f) (50). For skønhedens skyld må kunsten opgive det skønne: "Også for skønhedens skyld gives der intet skønt.mere" (đ̈.T. p. 85).

\section{Natur og kultur}

Med industrialiseringen og urbaniseringen fik naturen en ny skønhedsværdi som udtryk for det fremmedgiorte menneskes nostalgi. Naturen dukker i det 18. århundredes sidste halvdel og i det 19. århundrede op i kunsten som billede på menneskets længsel efter at træde ud af kulturen. Kunsten vil indløse, hvad naturen lover. Men Adorno understreger, at nostalgien ingen udvej er: 'Erindringen om friheden $\mathrm{i}$ det naturskønne fører vild, fordi den håber at finde frihed i den zldre ufrihed" (đ̈.T. p. 104) (52). (Det må her ikke glemmes, at Horkheimer og Adorno i "Dialektik der Aufklärung" karakteriserede antisemitismen som et kulturelt tilbagefald i en fremmedgjort natur).

Tingsliggørelsen er i dag så stor, at naturen ikke længere kan afbildes, men kun udtrykkes gennem negationen af kulturen: "Tro er kunsten kun mod den forekommende natur, når den viser landskabet $\mathrm{i}$ dets eget negative udtryk" (đ̈.T. p. 106) (53). Det er den natur, Samuel Beckett er tro, nảr han i "Slutspil" negativt skildrer en kultur, hvor naturen allerede er død.

Den moderne kunsts løsning er derfor ikke at vende tilbage til en oprindelig natur, for en sådan gives ikke, men i at kunsten bliver sig bevidst som "Geist". Adornos idealistiske sprogbrug vanskeliggør igen en forståelse. Adorno er enig med Hegel $i$, at kunsten adskiller sig fra empirien gennem at være "Geist". Det vil sige, at den som bevidsthedsform overskrider den blotte efterligning af virkeligheden (54).

Derimod protesterer Adorno mod Hegels identificering af kunst og tidsånd. For Adorno bliver "Geist" det samlende princip, hvorigennem kunsten protesterer mod de herskende tilstande. Den er "konfigurationen af de sanselige momenter" og er beslægtet med sandhedsindholdet uden at 


\section{2}

være det samme. Den er i modsætning til Hegels et processuelt moment i kunsten, ikke identisk med den.

Den modernistiske kunst er blevet sig uhy re bevidst som åndelig form for gennem arbejdet med form - og indholdselementer at kunne protestere mod samfundet. Adorno udtrykker det med et paradoks, hvor "Geist" først forstås i Adornos subversive betydning, dernæst i hegeliansk affirmativ: "jo mere substantiel åndeliggørelsen blev $i$ kunsten, desto mere energisk har den, såvel i Benjamins teori som i Becketts digteriske praksis, frasagt sig ånden, ideen” (Ä.T. p. 142) (55).

Kunsten har i denne proces inddraget traditionelt uæstetiske områder, hvorved den har solidariseret sig med de kræfter, det borgerlige samfund har fortrængt og lagt for had. Således kan kunsten som kulturprodukt pege frem mod en ny tilstand, hvor naturen ikke længere er undertrykt.

\section{De samfundsmcessige og de cestetiske produktivkrafter}

Den modernistiske kunsts "åndeliggørelse" hænger sammen med den almindelige udvikling af samfundets produktivkræfter. En sand kunst i dag kræver, at de æstetiske produktivkræfter er bragt på niveau med samfundets. Adorno siger om kunstneren: "Han legemliggør de samfundsmæssige produktivkræfter uden derved nødvendigvis at være bundet til de af produktivforholdene dikterede censurer, som han også altid gennem konsekvensen af sin metier kritiserer" (đ̈.T. p. 71) (56). Adorno er her på linje med Marx, når han peger på modsætningen mellem produktivkræfterne, der kunne anvendes til skabelse af et frit samfund, og produktionsforholdene, som skaber undertrykkelsen og forhindrer frigørelsen. Men Adorno tror ikke for alvor på muligheden af at ændre produktionsforholdene, eller blot på kunstens mulighed for at øve indflydelse på samfundets indretning. Udviklingen af produktivkræfterne har på én gang skabt mulighed for afskaffelse af den menneskelige nød, samtidig med at den reelle nød og undertrykkelse stadig øges.

Når Adorno således siger, at Sartre ikke er fulgt med udviklingen af de æstetiske produktivkræfter, mens Kafkas og Becketts kunstneriske teknik nøjagtigt svarer til udviklingen af de samfundsmæssige produktivkræfter, er han vist ikke ganske stringent $i$ sin tankegang. Produktivkræfterne er $i$ sig selv hverken undertrykkende eller frigørende, men bliver det forst inden for specifikke produktionsforhold. Kafkas og Becketts desperate billeder af et forvaltet samfund på vej mod katastrofen kan kun forstås i relation til det totale forhold mellem produktivkræfter og produktionsforhold.

\section{Form og indhold}

Formen er det centrale begreb i Adornos æstetiske tænkning. Gennem den 
distancerer kunsten sig fra empirien og opnår derved sin eksistensberettigelse: "Formbegrebet markerer kunstens antitetiske forhold til det empiriske liv, i hvilket dets eksistensberettigelse blev uvis. Kunsten har så stor en chance som formen og ikke mere" (A.T. p. 213) (57). Formen repræsenterer en magt over for den empiriske eksistens, hvis materiale tilpasses og omdannes i formens Prokustesseng. Gennem formens vold bliver kunsten i stand til at protestere mod volden i samfundet, fordi formen repræsenterer en subjektiv frihed, der ikke findes i empirien. Den kunstneriske form er den kritiske holdnings fundament: "Formen konvergerer med kritik. Den er det ved kunstværkerne, hvorigennem disse viser sig som kritiske i sig selv" (A.T. p. 216) (58). Formen tilslører ikke som filosofiens abstrakte begreber kvalitative forskelle, men bevarer modsigelserne i sin syntese og bliver derfor til en udfoldelse af sandhed.

Form og indhold står på denne måde $i$ et dialektisk forhold til hinanden, ja formen er selv sedimenteret indhold, og indholdet kommer kun til syne konkretiseret $i$ formen. Dialektikken i dette forhold betyder ikke, som Hegel eller f.eks. nykritikken ville hævde, at et kunstværk er en enhed. En sådan ville i Adornos øjne være en falsk forsoning.

I nutidens kunstværker er formen fragmentarisk og står i et spændt forhold til indholdet. Således er Becketts stykker principielt uden afslutning. Beckett anvender også traditionelle former i en tidsalder, hvor de ikke længere hører hjemme. Således overholder han i "Slutspil" de tre aristoteliske enheder som en bevidst anakronisme, hvorved stykket slår over i parodi (59).

\section{Kunsten som illusion}

Formen i kunsten betinger også dens karakter af illusion, dens "Schein". Som illusion løber kunsten den risiko at tilintetgøre sporene fra sin produktionsproces og som autonom kunstnerisk helhed at indgå som vare $\mathrm{i}$ den kapitalistiske konsumtionssfære. Den moderne kunst har protesteret mod dette og peget på sin egen skabelsesproces, (det ses i litteraturen f.eks. hos Thomas Mann, André Gide og Bert Brecht), uden derfor at kunne benægte, at illusionen er dens væsen og det, der adskiller den fra virkeligheden.

Adorno forsøger igen at gøre op med harmoniseringstendenserne inden for den hegelianske æstetik og den senere nykritik. Adorno indrømmer nok, at form og illusion er karakteristiske elementer i kunstens væsen, men han lader dem stå $\mathrm{i}$ et dialektisk forhold til deres modsætninger. Her opløses modsætningerne ikke, men fastholdes $\mathrm{i}$ deres uforenelighed: "Ethvert kunstværk er et system af uforenelighed" ( det moderne kunstværk mødes harmoni og disharmoni. Værkets enhed og dets detaljer forbliver uforsonet. 


\section{4}

Hos Valéry finder Adorno f.eks. en spænding mellem den kunstneriske konstruktion og tilfældigheden. Denne spænding tolkes som en bevidst protestholdning mod samfundet. Denne politisk set konservative kunstners praksis svarer til Brechts og peger frem mod dennes "Verfremdungs"-begreb. Valéry bruger ikke tilfældet som udtryk for blot umiddelbar subjektivitet, men lader det indgå $\mathrm{i}$ et kunstværk som det fremmedgjorte subjekts stemme midt $\mathrm{i}$ en rationel, objektiv lovmæssighed. Herved underkastes tilfældet helhedens rationalitet, samtidig med at det markerer dennes grænse. Valéry løser på denne måde i den kunstneriske form problematikken omkring subjekt/objekt-forholdet (61).

På en tilsvarende måde tackler den tyske modernist Hans G. Helms sit problem ved at lade tilfældigheden fungere som parameter. Herved manifesterer kunsten både sin frihed og sin afhængighed af den empiriske realitet. Adorno påpeger den tekniske lighed i denne fremgangsmåde med den serielle musik (62).

\section{Sproget og kunsten}

Formen er som nævnt hos Adorno den kategori, hvorigennem kunsten adskiller sig fra empirien. Sproget $i$ vid forstand er det medium, hvorigennem formen manifesteres. Derfor bliver sproget et centralt begreb i Adornos æstetik, især i arbejdet med litteraturen. Sproget er et socialt fænomen og deltager i opbygningen af samfundets ideologiske overbygning og konstituerer dets diskursive logik. I kunsten er sproget imidlertid i stand til at frigøre sig delvis fra den samfundsmæssige kommunikationstvang, hvorved kunstneren transcenderer det umiddelbart givne.

Sproget i litteraturen udgør således en dobbelthed, som både rummer de subjektive stemninger i sig, der protesterer mod den eksisterende slette almenhed, og de begreber, der forankrer den i den givne historiske situation og socialitet. Bedst bliver litteraturen, hvor subjektet går op $\mathbf{i}$ sprogets sande objektivitet. Adorno siger således i "'Rede über Lyrik und Gesellschaft": "De højeste lyriske frembringelser er derfor dem, i hvilke subjektet, uden rest af bart stof, toner i sproget, til sproget selv bliver hørligt" (N. z. L.I. p. 85 (63)).

Adornos sprogtænkning forholder sig logisk til refleksionerne over subjekt/objekt-problematikken. Hvor den umiddelbart givne almenhed i virkeligheden er repressiv og partikulær, peger individuationen mod en sand objektivitet. På samme måde bliver subjektiviteten i kunstværket formidler af den sande almenhed igennem sproget.

Adorno advarer imod at identificere denne sprogteori med Husserls og Heideggers fænomenologiske. Det sprog, der taler i kunstværket, er ikke den rene Værens stemme: "Selvforglemmelsens øjeblik, i hvilket subjektet dukker under i sproget, er ikke dettes offer til Væren" (N. og L. p. 86) (64). 
Det kunstneriske sprog er ikke ontologisk, d.v.s. at det ikke taler hinsides konkrete historiske forhold. Det peger derimod gennem subjektets sproglige manifestation hen på den sande objektivitet. Denne afvisning af fænomenologien hænger sammen med Adornos filosofiske udgangspunkt, at der intet oprindeligt gives. Kunsten artikulerer ikke Væren, men historisk tilblivelse: "Kunstens fænomenologi strander på forudsætningen om forudsætningsløshed. Kunsten spotter forsøget på at føre den tilbage til den rene væsensfylde. Den er ikke hvad den altid har været, derimod hvad den er blevet til" (Ä.T. p. 522) (65).

I det kunstneriske sprogs distance fra det empiriske, diskursive sprog ligger kunstens mulighed for protest mod de herskende tilstande. Den lober hermed en risiko for at ende i det rene, begrebsløse sprog og derved overskære forbindelsen til samfundet. Denne tendens ser Adorno i dele af den moderne lyrik. Men det er en risiko, der må løbes, for om muligt at nå frem til en kunst, hvor sproget bliver i stand til objektivt at udtrykke den menneskelige lidelse og drøm.

Den utopi, som kunsten, når den er bedst, fremstiller som negation af det værende, formidles gennem det, Adorno kalder udtryk eller mimesis. Udtrykket er forbundet med det sande almene. Det muliggør i kunsten en erkendelse af det falske i det værende og en længsel efter en ny, sand, menneskelig tilstand: "Udtryksfuld er kunsten, hvor det objektive, subjektivt formidlet, taler ud af den: sorg, energi, længsel, udtryk er værkernes klagende ansigt" (A.T. p. 170) (66). I udtrykket aflejres historiske processer, samtidig med at udtrykket bevarer et minde om noget sandt, som nu kun findes i kunstens billeder.

Den modernistiske kunsts forsøg på at skabe rent udtryk er altså resultatet af et oprør mod det kommunikative sprog i en længsel efter det rene udtryk. Denne tendens aflæses tydeligt i prosaen fra Joyce og fremefter. Udtrykket siges med en noget mystisk formulering at høre hjemme i subjektivitetens urhistorie (67). Det må imidlertid ikke forstås fænomenologisk), som en umiddelbar Væren, men som det formidlede subjekts relation til en sand objektivitet.

"Udtrykket" er hos Adorno identisk med "mimesis". Dette begreb har hos ham en noget anden betydning end den traditionelle aristoteliske. Hos Aristoteles betød det ganske vist en kunstnerisk formet efterligning af virkeligheden og ikke den blotte reproduktion, men klassicismen fortolkede det som en efterligning af naturen. At der var tale om et abstrakt og yderst renset og stiliseret naturbegreb er så en ganske anden sag. Med det 19. og 20. århundredes litterære realisme og naturalisme knæsættes begrebet mimesis som den blotte efterligning af virkeligheden (68).

For Adorno er mimesis det modsatte af realisme. Realismen er iflg. ham en borgerlig, kunstnerisk retning, udsprunget af en borgerlig, tingsliggjort bevidsthed. Mimesis er derimod Adornos begreb om de positive værdier, 
der ikke længere kan gribes af et abstrakt filosofisk system, men som det kunstneriske udtryk kan give et billede af. Mimesis kan ikke defineres, fordi det ikke kan benævnes af et kommunikativt sprog, men kan alligevel i kunsten fungere som udtryk for den sande objektivitet.

I mimesis er kunstens utopiske intention -funderet (69). Mimesis er således immanent $\mathrm{i}$ den sande kunstneriske proces, hvorigennem det objektive finder sit sprog. Derfor er den kunstner, der forholder sig objektivt til sin kunstform i stand til at udtrykke det. Adorno kan således tale om Becketts immanente sagfornuft.

Begrebet mimesis implicerer ikke en teori om kunsten som rent sprog. Det kunstneriske sprog kan og skal ikke frigøre sig fuldstændig fra det kommunikative sprog, men eksistere i spændingen mellem dette og mimesis.

Midt mellem rent udtryk og kommunikativt sprog eksisterer kunsten som en gåde eller som et kryptogram, hvis skrift man endnu ikke kender koden til (A.T. p. 188). Kunsten forholder sig i Adornos tænkning til et fornufts - og et naturbegreb, som udgør teoriens utopiske fundament. Habermas skriver rammende om denne utopi: "For utopien gælder billedforbudet så strengt som for jødernes messianske fremtid" (Habermas: Ein philosophierender Intellektueller. Über Theodor W. Adorno p. 41) (70).

Ligesom utopien ikke kan konkretiseres uden at miste sit indhold, så fungerer mimesis, natur og sand fornuft som billeder på noget uudsigeligt, som gådeskrift. De kan ikke henvises til et eksisterende naturbegreb, fordi denne natur allerede er fremmedgjort for sig selv. De kan ikke udmøntes i et alternativt filosofisk system, fordi det at sætte en teori på begreber for Adorno er identisk med at forråde den og udlevere den til det bestående. Kun i kunstens negative billede bevares troskaben mod dem.

Da sprogtænkningen er central i Adornos æstetiske refleksioner, vil jeg illustrere min gennemgang med et par eksempler hentet fra Adornos litteraturkritiske analyser.

I "Rede über Lyrik und Gesellschaft" analyserer Adorno to digte. I Mörikes "Auf einer Wanderung" påviser han digtets modstilling af to sproglige stillag, en klassicistisk, høj stil med vægt på en abstrakt almen menneskeopfattelse, og en romantisk stils private miniature. Digtets kvalitet ligger $\mathrm{i}$ dets balance, hvorigennem begge litterære retningers begrænsning neutraliseres og kompenseres ved den andens tilstedeværelse. Det almene og det individuelle afbalanceres mod hinanden.

I Stefan George-digtet (N.z.L., p. 98) påviser Adorno Georges antiborgerlige holdning i hans flugt fra det kommercielle sprog. Digtet forsøger at gøre sig til beholder for et rent sprog. Digterens følelse af at være fremmedgjort over for dagligsproget fører ham frem til skabelse af et imaginært sprog. Den antiborgerlige holdning førte hos George til en 
længsel tilbage mod feudaltiden. Jeg tror imidlertid, at årsagen til Adornos forkærlighed for dette specielle digt ligger $i$, at det blot gennem sproget udtrykker længselen uden at tematisere og dermed "ideologisere" den.

Særlig begejstret er Adorno for digtets fire sidste linjer: "Nun muss ich gar/ Um dein aug und haar/ Alle tage/ In sehnen leben", hvor ordet "gar" ikke synes at have nogen betydningsfunktion ud over den væentlige at fungere som sproglig vellyd. Brugen af ordet demonstrerer Georges flugt fra et entydigt kommercielt sprog mod et funktionsløst og skønhedsdyrkende. Med nogle marxistiske termer, som Adorno selv anvender i sin æstetiske teori, kan man sige, at George opfatter det kunstneriske sprog som brugsværdi i modsætning til det kommercielle sprogs bytteværdi. Hans sprog bliver billede på længselen efter det umulige, som det hedder i Adornos her næsten ontologiske tænkning: "Sprogets chimæriske længsel efter det umulige bliver til udtryk for subjektets evige erotiske længsel efter at frigøre sig i den anden" (N. z. L. p. 103) (71).

I essayet "Parataxis" om Hölderlins sene lyrik har Adorno skrevet en af sine mest inspirerende litterære analyser, og han har med stor dygtighed brugt sproglige iagttagelser i fortolkningen. Han indleder med en polemik mod Heidegger, der selv har skrevet en bog om Hölderlin ("Erläuterungen zu Hölderlins Dichtung"). Fra den citerer Adorno Heideggers ord: "Men ursprog er digtningen som stiften af væren" (N.z.L. III, p. 163) (72), som tydeligt viser sprogontologiens tro på digtningen som udtryk for den sande Væren.

Mod Heidegger hævder Adorno, at digtningens sandhed ikke ligger i indholdet, men $i$ den kunstneriske form, og at den sande forståelse af samfundskritikken og utopien hos Hölderlin ikke findes i hans umiddelbare tanker, men i den æstetiske sprogholdning. Hölderlin opfatter ikke historien som en kraft, der udfolder sig i den rene Væren, men han anklager gennem sproget historien for at have skabt en kløft mellem det værende og det sandes væsen.

I Hölderlins sprog forsvinder det reelle, fordi det fortjener at forties. Sproget udsiger sin dom over det bestående. Af genstandsverdenen forsvinder, demonstrerer den historiske adskillelse af subjekt og objekt. Digterens had til det værende afspejles $\mathrm{i}$ hans allergi mod de sproglige konventioner og det forventede udtryk: "Han [Hölderlin] var allergisk mod det alt for ventede, det allerede indfangne og byttelige $i$ den sproglige konvention" (N.z.L. III, p. 183f) (73). Mod den herskende sproglige logik sætter Hölderlin en musikalsk, hvorved der sker en bevidst opløsning i det sproglige indhold.

I modsætning til de græske hymners hypotaktiske opbygning, som hos Pindar, er Hölderlins parataktiske. Det vil sige, at de ikke er struktıreret omkring en enkelt tanke (logos), og at de ikke følger en logisk over- og underordningsstruktur. Herved modsætter de sig dels det kommunikative 


\section{8}

sprogs logik, dels den klassicistiske æstetiks krav om harmoni. Ved at frigøre sproget fra det umiddelbart værende håber Hölderlin at skabe et nyt sprog. Gennem abstraktionen forsøger han at nå frem til ny konkretion.

Hölderlin tilstræber ikke normalsprogets syntese, men en sprogkritisk selvrefleksion. Han vil frigøre sproget fra den diffuse natur og gøre den til kultur $\mathrm{i}$ oprindelig forstand, det vil sige $\mathrm{i}$ form af modtaget natur. Med andre ord sigter Hölderlin mod en kultur, som ikke længere er repressiv over for naturen.

Hölderlins utopi har ingen konkret basis i den objektive virkelighed, men er funderet $i$ hans sproglige holdning, hvor ordene bruges suggestivt mod logikkens undertrykkelse. Myterne anvender han i sin lyrik mod de herskende myter, det vil sige til afmytologisering. Således bliver Hölderlins hang til myter og romantik en refleksion, der sættes ind mod det bestående samfund.

Fælles for George og Hölderlin er, at de begge i protest mod det kommunikative sprog stræber mod et renere og mere autentisk. Becketts kamp mod den herskende logik har samme sigte, men bevæger sig ad andre sproglige baner. Her opløses kommunikationssproget gennem overdrivelse og parodi, hvorved dets absurditet træder frem. Beckett vender sig ikke fra dagligsproget, men overd river og afslører det.

I sin analyse af "Slutspil" viser Adorno, hvordan det nuværende sprog hos Beckett er slået over i uforståelighed. Stykkets mening bliver således dets mangel på mening. De filosofiske brokker, de indre monologer, de hundrede klicheer kommunikerer, at der ikke længere gives nogen kommunikation: "Kommunikationen, klichéens universelle lov, forkynder, at der ikke mere er nogen kommunikation" (N.z.L. II, p. 219) (75).

Ligesom den historiske udvikling af Beckett forlænges frem til et historisk tidspunkt, hvor selv tiden er ved at høre op, på tærskelen til den totale, menneskelige udslettelse, på samme måde føres en sproglig udvikling videre til den totale absurditet, mod hvilken sproget allerede længe har bevæget sig. Drevet til dette punkt kan Becketts kunst dialektisk vende sig mod tilskueren (læseren), som ængstes for, at det, han hører og ser, også gælder ham selv: 'Som den vågne erfaring efter intensiv læsning af Kafka mener at iagttage alle slags situationer fra hans romaner, så bevirker Becketts sprog en sund forværring af den syge: den dèr hører sig selv ængstes for, om han ikke taler lige sådan" (N.z.L., p. 218) (76). Det transcenderende moment i Becketts kunst ligger i denne advarsel. Hans sprogholdning fører således ligesom Hölderlins og Georges til en konfrontation mellem det usande værende og en mulig, ikke-konkre tiseret, sandere eksistens. 


\section{Adornos æestetik og dens forhold til klassicisme, realisme og modernisme}

\section{Klassicismen}

Adornos opgør med opfattelsen af kunst som harmonisk form er også et opgør med den klassicistiske æstetik. Dennes harmonilære hænger sammen med et repressivt samfundssyn. Teorien om kunstværket som en lukket helhed har sin rod $i$ et lukket samfund: "Engang i lukkede samfund har ethvert kunstværk besiddet sted, funktion og legitimation og er derfor blevet velsignet med lukkethed, mens der $\mathrm{i}$ dag bygges $\mathrm{i}$ det tomme og kunstværket fordømmes til at kæntre" (А.T. p. 236) (77). I dag hvor det lukkede samfund er blevet problematisk, ser kunsten i harmoniidealet en fare for tilpasning til den forvaltede verden.

Den klassiske, græske kunst postulerede en enhed mellem det almene og det individuelle, som ikke fandtes i samfundet. Denne falske forsoning røbes kunstnerisk i de klassiske statuers tomme øjne, der snarere udstråler angst end "edle Einfalt und stille Grösse", hævder Adorno polemisk mod Winkelmanns traditionelle fortolkning af den græske kunsts væsen (78). At den græske kunst bevarede en vis storhed i formen skyldtes, at den ikke fornedredes af det kristelige seksualtabu over den sanselige verden.

Den græske klassisk opkomst er forbundet med kampen mod myterne og med den begyndende filosofiske tænkning. Den opstår derfor som en antitese $\mathrm{i}$ forhold til den mimetiske impuls og bygger således ligesom den videnskabelige, rationelle tankegang på undertrykkelse af naturen, (jvfr. Horkheimers og Adornos fortolkning af Odysseen). Den nyklassicistiske kunst bevarer den undertrykkende tendens, idet den på den abstrakte almenheds vegne øver vold mod det individuelle.

Både Kants og Hegels æstetik lider som for påvist af, at de hævder et abstrakt almenbegreb. Kant glemmer, at det almene velbehag, som kunsten iflg. sit væsen vækker, ikke er almengyldigt, men underlagt samfundets konventioner. I modsætning hertil er Hegels almenbegreb dialektisk, men det er samtidig ideologisk, idet det sætter det virkelige lig det fornuftige. Herved forsøger Hegel at skjule det herskende systems abstrakte karakter og at neutralisere kunstens individuelle revolte.

Selv om Adorno ikke siger det direkte, synes hans kritik af det klassicistiske harmonibegreb også at ramme den angelsaksiske nykritik, der ser den store digtning forsone sine iboende modsætninger. Nykritikken, først og fremmest I.A. Richards og Cleanth Drocks, hører jo også via Coleridge, der var fortrolig med sin tids tyske filosofi, hjemme $\mathrm{i}$ den idealistiske tradition.

En af klassicismens fejl var, at den ikke tænkte forholdet mellem form $\mathrm{og}$ indhold dialektisk, men a priori krævede bestemte formkonventioner overholdt. Derfor bebrejder Adorno Valéry, der ellers på mange måder har 
160

vøeret med til at formulere væsentligt modernistiske erfaringer, at han på nyklassicistisk vis retfærdiggør formen udefra: "Men Valéry viser sig sammensvoren med nyklassicismen ved at retfærdiggøre udefra satte former, uafhængigt af formens immanens inden for hver enkelt frembringelses lovmæssighed" (Valéry Abweichunge. N.z.L. II, p. 84) (79). Denne æstetiske konformisme får konsekvenser for Valérys samfundsmæssige holdning.

Men i praksis overskrider Valéry of te det dogmatiske formbegreb og skaber et andet, hvor det arkitektoniske og det musikalske syntetiseres uden at de to områders forskellighed tilsløres. Herved undgår Valéry klassicismens harmoniseringstendens og udtrykker modernismens indsigt $i$ det bestảendes uforsonlighed.

\section{Realismen}

Realismen er den anden kunstneriske retning, Adorno angriber. Den er såvel $\mathrm{i}$ den vestlige som $\mathrm{i}$ den østlige verden udtryk for en borgerlig bevidsthed. Den opfatter den empiriske eksistens som den eneste mulige og lænker derved kunsten til den herskende ideologi, og ved at benægte kunstens forskellighed fra empirien berøver den kunsten dens utopiske mulighed.

Den kunstneriske realisme er i sin troskab mod den empiriske detalje beslægtet med kulturindustrien. Det amerikanske fjernsyns repressive funktion, viser Adorno, består netop i minutiøs gengivelse af den umiddelbare virkelighed, hvorved seeren bibringes det indtryk, at den samfundsmæssige realitet er den eneste mulighed, der gives (80). Den realistiske kunst løber samme mulighed for at blive indrangeret $\mathrm{i}$ det kulturindustrielle ja til det bestående. Sartres realistiske form og håndfaste plots integrerede ham sảledes mod hans egen vilje i kulturindustrien.

Polemikken mod realismen er dog først og fremmest rettet mod den traditionelle sammenkædning af marxistisk filosofi og realistisk kunst. Men, siger Adorno: "Slutningen fra filosofisk materialisme til æstetisk realisme er falsk" (A.T. p. 383) (81). En materialistisk æstetik kræver som tidligere nævnt, at de æstetiske produktivkræfter er på niveau med de samfundsmæssige. Den realistiske æstetik svarer til højkapitalismens opkomst i Vesteuropa o. 1830-1870. Det gælder for såvel de æstetiske som de samfundsmæssige produktivkræfter, at deres udvikling er irreversibel, og at man derfor ikke kan kræve en tilbagevenden til en tidligere æstetisk tradition. Det stalinistiske krav om realisme i kunsten bliver derfor en regression med ulykkelige konsekvenser i form af undertrykkelse $\mathrm{i}$ både den kunstneriske og den politiske verden.

Klarest er Adornos polemik mod marxismens krav om realisme kommet til udtryk i opgøret med Georg Lukács i anledning af dennes bog 'Wider 
den misverstandenen Realismus". I denne havde Lukács bebrejdet den modernistiske litteratur, at den var både formalistisk og dekadent og havde over for den fremhævet den borgerlige og socialistiske realisme som eksempel.

Lukács' kritik af formalismen i modernismen skyldes iflg. Adorno hans undervurdering af formens objektive moment, d.v.s. dens dialektiske forhold til den historiske situation. Dyrkelsen af formen i modernismen er ikke udslag af individers griller, men funderet $i$ en bestemt objektiv situation. I sin kritik er Lukács fundamentalt udialektisk.

Tilsvarende borgerligt og udialektisk er begrebet dekadent, idet det som sin modsætning implicerer en bestemt forestilling om en sund natur. Sundheden placeres selvfølgelig inden for den socialistiske æstetik og politik, hvorved Lukács uundgåeligt kommer til at forholde sig bekræftende $i$ forhold til det herskende system $i$ de socialistiske lande og fornægte den undertrykkelse, der reelt finder sted: "Altid hvor der tordnes mod dekadence, gentager denne flugt sig. Lukács tvinges til den gennem en tilstand, i hvilken den samfundsmæssige uret varer ved, samtidig med at den officielt er erklæret afskaffet" (Erpresste Vesöhnung N.z.L. II, p. 84) (82).

Ligesom Lukács ikke forstår formens dialektiske betydning, så skelner han ikke mellem kunst og virkelighed. Han fornægter kunstens karakter af illusion, dens "Schein", og hæuder en udialektisk spejlteori. Dette resulterer f.eks. i fejlagtige paralleliseringer mellem filosofi og kunst, som når Lukács tror at genfinde Heideggers ontologisering hos modernistiske digtere som Proust, Kafka, Joyce og Mann.

Skildringen af den menneskelige ensomhed hos modernisterne er ikke udtryk for en ontologisk tilstand, men er et formidlet billede af menneskets situation $i$ et givet samfund. Kunstens immanente komponenter, dens væesen (Wesen) og billede (Bild) er ikke identiske med ontologiens tilsvarende, tværtimod udgør de kunstens forsvarsvåben mod det værende, og gennem dem bliver kunsten dialektisk.

Angrebet på Lukács sætter ligesom kritikken mod Sartre og Brecht ind på to beslægtede punkter. Dels foretager Lukács ligesom de to andre en forkert vurdering af den historiske situation, dels forstår han ikke, at udviklingen af de æstetiske produktivkræfter forløber parallelt med udviklingen af de sociale. Han tillægger subjektet en mulighed for at handle, som objektivt ikke er til stede i dag: "Det er ikke muligt for det enkelte subjekt gennem valg og beslutning at ná ud over den kollektivt determinerede ensomhed" N.z.L. II, p. 171 (83). Kunsten må på grund af samfundet forblive kontemplativ og kan ikke omsættes i praksis. Lukács klage over modernismens mangel pá verden, skyldes hans egen manglende forstålse af denne verdens nuværende situation.

Lukács realismebegreb, der inkluderer både den borgerlige og den 


\section{2}

socialistiske, er konsekvensen af hans manglende forstảelse for udviklingen i de æstetiske produktivkræfter. Realismen er udtryk for en borgerlig bevidsthed og bruges af den osteuropæiske bevidsthedsindustri til at camouflere den politiske repression. Lukács ender sâledes selv i en idealistisk faldgrube ved, som Hegel i retsfilosofien at betragte det virkelige som det fornuftige og afpresse kunsten en forsoning, som er falsk. Derved udsiger han i virkeligheden blot det østeuropæiske samfunds sygdom.

De borgerlige realistiske kunstneres storhed bestod iflg. Adorno i deres mangel på realisme. Dette demonstrerer han i et interessant essay om Balzac, "Balzac-Lektüre" (N.z.L. II), hvor Adorno forholder sig kritisk over for den traditionelle marxistiske æstetik, der plejer at stille Balzac op som idealet på den realistiske forfatter (jvfr. Marx selv, Engels, Gramsci og Lukács).

Balzac kaldes af Adorno "den første sådanne paysan de Paris" (N.z.L. II, p. 19) (84). Samtidig inkarneres i ham borgerskabets produktivkræfter på tærskelen til højkapitalismen. Dette medfører, at Balzac både står uden for samfundsudviklingen som en forundret og kritisk tilskuer, og er integreret $\mathrm{i}$ den. Denne dobbeltholdning afspejles i den kunstneriske forms svingning mellem det fantastiske og det realistiske. I hans romanfigurer mødes personernes menneskelige egenskaber med deres samfundsmæssige funktion, som tvinger dem til at handle på en bestemt måde. Menneskene bliver derfor karaktermasker eller marionetter i det økonomiske spil, hvor folk med positive, menneskelige egenskaber uvægerligt går til grunde. Balzac ligger ikke under for den borgerlige illusion, at individet har betydning, men skildrer, hvorledes den menneskelige psyke fødes i og determineres af samfundet.

Med sin rod i den førborgerlige (feudale) tid ser Balzas irrationaliteten $\mathrm{i}$ den borgerlige rationalitet. Forankringen i den forkapitalistiske tid giver hans værk et romantisk aspekt, mens den samfundsmæssige situation slår ned i den realistiske form.

Balzacs brug af mange konkret detaljer er ikke udtryk for en objektiv beherskelse af virkeligheden, men snarere for en angstfuld følelse af at blive overvældet af det reelle. I ophobningen af detaljer minder han om en skizofren. Verden er blevet fremmed for ham. Hans realisme er sảledes ikke resultatet af en beherskelse af virkeligheden, men udtrykker en følelse af realitetstab: "Realismen, som også idealister hengiver sig til, er ikke primær, men derimod afledet: realisme af realitetstab. Epikken, som ikke længere er den genstandsverden mægtig, som den søger at rumme, mả sin vane tro overdrive, beskrive verden med alt for stor nøjagtighed, netop fordi den er blevet fremmed og ikke længere lader sig holde i kropsnærhed"' (N.z.L. II, p. 29f) (85).

Den næsten skizofrene besættelse over for detaljen, erkendelsen af at den samfundsmæssige helhed ikke længere lader sig overskue, og at 
subjektet intet formår over for det almene, er træk i Balzacs værk, der peger ud over realismen og frem mod modernismens "entartede" kunst, som Adorno ironisk kalder den med henblik på såvel nazismens som kommunismens fordømmelse af den dekadente, ikke-realistiske kunst. Balzacs manglende realisme bliver hans kunstneriske styrke, fordi den viser, at han ikke identificerer sig med det værende $\mathrm{i}$ det kapitalistiske samfund, men gennem den negative kunstneriske artikulation af det bestånde udtrykker ønsket om, at det var anderledes.

Marx' og Engels beundring for Balzac skyldtes, at han til trods for sit personlige, reaktionære politiske stásted blev talerør for en objektiv kritik af kapitalismens væsen. Adorno påviser, hvorledes denne kritik har sit fundament $\mathrm{i}$ den ikke-realistiske form og făr derved elegant brugt "kirkefædrenes" egne tanker mod den herskende marxistiske æstetik.

\section{Modernismen}

Det er mange gange i opgaven blevet fremhævet, at Adorno mener, at den modernistiske kunst svarer til de nuværende æstetiske produktivkræfters udvikling. Modernismen er det sande svar på den forvaltede verden. Den er det, fordi den hverken lader sig indfange af et begreb om umiddelbarhed eller bukker under for den samfundsmæssige fornuft og dermed bliver realistisk. Den fastholder kunstens autonomi, fordi den derigennem kan distancere sig fra empirien, samtidig med at den erkender sit dialektiske forhold til det værende og derved undgår at blive vare på det borgerlige samfunds marked.

Gennem formen tager den modernistiske litteratur afstand fra det kommunikative sprog og begrebets tyranni, samtidig med at den indrømmer sin afhængighed deraf. I den forvaltede verden, hvor det bestående behersker kommunikationen, kommunikerer kunsten det ukommunikerbare. Ligesom den kritiske teori negerer samfundet som totalitet, gør den modernistiske kunst det. I dens totale negativitet, og ikke i et positivt formuleret alternativ, ligger dens utopiske mulighed. Ved at udsige hvor forfærdeligt det er, peger modernismen pá, hvordan det burde vaere.

Samuel Beckett er nok den forfatter, Adorno føler sig mest beslægtet med, og man kan i udgivernes efterskrift læse, at Adorno havde til hensigt at tilegne Beckett den æstetiske teori. Analysen af "Slutspil", "Versuch das Endspiel" zu verstehen (N.z.L. II) hører også til de mest spændende blandt Adornos essays, og kan belyse den nære sammenhæng mellem den modernistiske litteratur og Adornos æstetik.

Beckett aflæser i "Slutspil" den historiske situation ved at føre dens konsekvenser til den ekstreme grænse, hvor verden står pá randen af den totale udslettelse. Han fuldfører den allerede for længst påbegyndte opløsning af det menneskelige subjekt. Herved afslører han den eksistentia- 
164

listiske illusion, at subjektet har en mulighed for at gribe ind i udviklingen. Tiden er næsten hørt op med at eksistere, og historien udelukkes, fordi den i sin borgerlige form har udtørret bevidsthedens kraft til overhovedet at tænke historien.

Becketts personer opfører sig primitivt-behaviouristiske som mennesker efter katastrofen - eller, som Adorno siger med et præcist billede, som fluer der farer hid og did efter at være ramt af fluefangeren (86). Men denne tilstand af regression er ikke en ontologisering fra Becketts side, men en protest mod en verden, hvor der snart intet alternativ findes til regressionen: "Den protestløse fremstilling af nutidig regression protesterer mod en verdenstilstand, der sá villigt adlyder loven om regression, at den egentlig ikke længere råder over noget oppositionelt begreb til at måle regressionen med" (N.z.L. II, p. 198) (87).

Denne verden befinder sig $\mathrm{i}$ en tilstand, hvor der ikke længere findes natur. Tingsliggørelsen er fuldendt, katastrofen i fuld gang. I den verden udspiller de to hovedpersoner et tvetydigt spil. Herren, Hamm, onsker at dø, lige så vel som at leve videre som herre, slaven, Clow, ønsker at gøre oprør, samtidig med at han af egen vilje masochistisk forbliver i sin tjenerrolle.

Beckett opløser genrebegreberne tragedie og komedie. Det tragiske går over i klovneri, og det komiske latterliggøres og dødsdømmes. Sproget kommunikerer, at der ikke længere kan kommunikeres. Becketts absurde logik opløser ikke det rationelle som verdensanskuelse, men lader det komme til sig selv, d.v.s. afslører det i dets egentlige irrationalitet.

Absurditeten lader den historiske uafvigelighed komme til syne i hele dens vanvid. Derved bliver Becketts negative ontologi ikke ontologisk $i$ filosofisk forstand, men en negation af ontologien. Der àbnes mulighed for gennem negationen at nå frem til noget sandt. Men den historiske situation er sådan, at denne sandhed end ikke kan tænkes.

Tanken om døden bliver håbet for stykkets to hovedpersoner. Intetheden og forsoningens ro finder her sammen. Ved at gøre døden til det eneste håb fastholdes den totale negation af den bestảende verden. Kun i den negerende holdning ser Beckett en mulighed. At Adorno læser Beckett som nutidens sande historieskriver, viser den dybe pessimisme, der inderst inde behersker hans filosofi og æstetik.

\section{En kritik af Adornos teori}

Som påvist er holdningen i Adornos æstetiske teori i fuldstændig overensstemmelse med den kritiske teoris filosofiske udgangsposition. Det vil sige, at en kritik af Adornos æstetik nødvendigvis også må blive en kritik af hans filosofi og samfundsopfattelse. Adorno kalder sin teori for materialistisk-dialektisk og henter sine æstetiske normer fra en analyse af 
den historiske situation. Han må derfor også finde sig $i$ at blive underkastet en dialektisk kritik. Kemen $i$ hans teori er kravet om, at de æstetiske produktivkræfter skal være pà niveau med de sociale. Netop ved at tage dette krav på ordet og undersøge om Adornos æstetik svarer til en adækvat analyse af samfundet $i \mathrm{dag}, \mathrm{kan}$ man tage stilling til dens relevans.

Horkheimers og Adornos filosofiske teori opstod som næunt i en tid, hvor den tyske arbejderklasse støttede Hitler, og den amerikanske syntes integreret i det kapitalistiske samfund. Den ældre Frankfurterskole udledte deraf, at, til trods for at klassemodsætningerne stadig reelt eksisterede, var det definitivt lykkedes det vestlige monopolkapitalistiske samfund, dels gennem øget velstand, dels gennem en fuldstændig bevidsthedsmanipulation at tilsløre modsætningerne og integrere arbejderklassen. Endelig havde marxismen i østlandene udviklet sig til en undertrykkelsesideologi, hvorved den syntes at have forspildt sine muligheder som revolutionær teori. I denne historiske situation opstod Frankfurterskolens teori om den forvaltede verden eller det endimensionale samfund og dens kamp mod enhver form for abstraktion og systematisk tænkning.

De sidste års udvikling har imidlertid delvis dementeret den pessimistiske tanke, at kapitalismen er i stand til at tilsløre alle sine modsætninger. Studenteroprøret har hos mange skabt en bevidsthed om undertrykkelsen både på det internationale plan (imperialismen) og det indenrigspolitiske (undertrykkelsen af proletariatet). Arbejderne har i mange lande, især de højt industrialiserede, gennem strejker demonstreret deres utilfredshed. Hvor dybt denne går, er selvfølgelig endnu umuligt at sige, men ihvertfald har utilfredsheden fảet sả mange stemmer, at teorien om den forvaltede verden i dag synes tvivlsom.

Endelig kan man pege på, at optøningen af den kolde krigs fronter bl.a. har fort til et nyt videnskabsteoretisk arbejde med Marx' tanker, og at stalinismens pervertering af marxismen således ikke for stedse har blokeret for muligheden af en revolutionær, politisk og videnskabelig teori, bygget på marxistisk grundlag.

Jeg vil i det følgende henvise til to kritiske artikler om Adorno: Bernard Willms" "Theorie, Kritik und Dialektik" fra "Über Theodor W. Adorno" og Göran Therborns generelle opgør med Frankfurterskolen i "Från revolutionär teori til akademisk metafysik", "häften för Kritiska Studier" 5 og $6-1969$. Willms er vel nærmest hegelianer, mens Therborn er af marxistisk-leninistisk observans. Der er imidlertid et forbløffende sammenfald i deres kritik, som rammer noget fundamentalt i Adornos filosofi.

Det, Willms kritiserer, er Adornos begreb om det almene, hvor samfundet opfattes som en stor almenhed. Når samfundet i dets totalitet betragtes som falsk, kan en alternativ tænkning ikke forankres konkret i samfundet, men må hente sit indhold udefra. Den bliver så til utopi, som kun kan beskrives i abstrakte termer som fornuft, frihed eller sandhed: 
"Men når sandheden er helheden, men helheden kun samfundets uvæsen, så bliver subjektiviteten i bestemmelsen af friheden til utopi" (Über Theodor W. Adorno, p. 61) (88).

Hvis helheden er usand, kan den ikke kritiseres konkret. Derfor ender Adornos kritik $\mathrm{i}$ en subjektiv attitude (der dog ikke er identisk med Kierkegaards), hvor den má erkende, at den intet alternativ kan opstille. Den rene kritik bliver sảledes uden kritisk mulighed, fordi den til trods for sit foretagende i virkeligheden forbliver udialektisk. Teorien bliver en teori om umuligheden i teori. Den bliver en teori uden praksis, og dens utopi forvandles derfor til perversion: "Hvis teori betyder handlingsaskese, så er utopien dens nøjagtige perversion" (opus cit. p. 88) (89).

Göran Therborn demonstrerer også, hvorledes Frankfurterskolens fundamentale svaghed er "dess karaktär av absolut negation av det borgerliga samhället" (90). Den kritiske teori bliver pá denne måde ikke en videnskabelig teori, fordi dens beskrivelse af klassesamfundet er mangelfuld, og heller ikke en politisk teori, fordi den giver afkald pà praksis. Frankfurterskolen er reduktionistisk, idet den nivellerer alle forskellige problemstillinger til et opgør med den naturvidenskabelige tænkemåde. Dens sætten lighedstegn mellem kapitalisme og fascisme er udslag af en sådan reduktion, som underkender konkrete, historiske forskelle (91).

Utopien $\mathrm{i}$ forhold til den forvaltede verden finder Adorno i den modernistiske kunst. En anfægtelse af Adornos totale negation af samfundet vil derfor også kaste et kritisk lys over hans kunstopfattelse og hans forhold til modernismen. Hvis samfundet ikke opfattes som totalt slet, men som et klassesamfund med antagonistiske kræfter, af hvis skød et nyt socialistisk samfund muligvis kan fødes, sả bliver der ikke behov for en utopi, men en dialektisk-materialistisk teori om samfundet.

Kunsten bliver sả heller ikke længere utopiens hellige sted, men en bestemt skrift inden for bestemte produktionsforhold. Den modernistiske kunst bliver så heller ikke længere det adækvate udtryk for produktivkræfternes udvikling, men et begreb, som en ny kunst og en ny æstetisk teori må forholde sig kritisk til.

Forøvrigt er Adorno som tidligere nævnt ikke stringent i sin brug af de marxistiske begreber. De æstetiske produktivkræfter er ikke blot et resultat af udviklingen i de sociale, men står også i relation til de konkrete produktionsforhold. Hvis Kafkas og Becketts tingsliggjorte verden kun er kunstnerisk udtryk for produktivkræfternes stade, så må deres værker læses som blotte beskrivelser af angsten for teknologien. Dette kan ikke være meningen, og er det heller ikke hos Adorno, som i sin fortolkning af modernisterne ganske klart opererer med en opfattelse af de repressive produktionsforhold.

Modernismen er, som Adorno fremhæver, et kunstnerisk udtryk for den likvidation af det individuelle menneske, som foregår under de kapitalisti- 
ske produktionsforhold. Subjektet overvældes af det "objektive" og forsvinder. I denne opfattelse overvældes imidlertid ogsả både modernisterne og Adorno selv af begrebet det objektive, idet de ser det som en totalitet og ikke som en modsætning mellem klasser. Derved prisgiver man den mulighed, den være sig nok så lille, for revolutionær praksis, som ligger i denne modsætning. Denne mulighed mả det være en post-modernistisk kunsts opgave at artikulere i kunstnerisk form, og det må være en post-adornosk æstetiks opgave, ikke at lovgive for, men filosofisk at reflektere denne kunst.

Dette betyder ikke et krav om tilbagevenden til kunstnerisk realisme, for jeg tror, at Adornos kritik af realismen som en borgerlig kunstform er yderst præcis. Derimod vil det nok blive en kunst, som mere dialektisk forholder sig til konflikten mellem det subjektivt mulige og det objektive, og en kunst, som mere bevidst giver et billede af dé samfundsmæssige modsætninger.

Adornos indsigt i den kunstneriske forms betydning er værdifuld, fordi den forhindrer en alt for letkøbt parallelisering mellem kunst og filosofisk tænkning. Sáledes mener jeg, at Adornos pảpegning af, at den modernistiske litteratur ikke, som Lukács påstår, er ontologisk i Heideggersk forstand, er rigtig. Modernismen er sig derimod bevidst som dialektisk billede, uden at dens historiske opfattelse derfor behøver at have evig gyldighed.

Faren ved Adornos formbegreb er imidlertid, at det let ender i en fetischdyrkelse af formen som væsen. Formen er ikke et transcenderende moment i sig selv, men mả bedømmes i sin konkrete skikkelse i relation til indholdet.

Adorno tager afstand fra fænomenologiens sprogontologi, der betragter digtningen som Værens autentiske stemme og understreger sprogets historiske forankring. Alligevel er Adorno selv ved at ende i samme grøft, f.eks. i analyserne af George og Hölderlin. Jeg tror, det skyldes Adornos uklare utopibegreb. Det er nemlig i sproget, at Adorno ser utopien komme til syne, og det er endda ikke i det, spioget kommunikerer, men i det, det ikke siger, at hảbet om et bedre samfund kan anes.

Troen på det rene, funktionsløse udtryks slægtskab med sandheden er for mig at se blot ideologisk og reducerer mod Adornos vilje kunsten til fetisch. At det kunstneriske udtryk står i dialektisk forhold til sảvel realitetsprincippet som lystprincippet er rigtigt, men at definere kunsten negativt ud fra det første og positivt i forhold til det andet betyder blot at reducere kunsten til uforpligtende skønhedsdyrkelse. Det er trods alt ikke kun magthaverne, der kommunikerer. Adorno er $\mathrm{i}$ en nødvendig reaktion på den traditionelle marxistiske æstetiks enøjede indholdsdyrkelse, endt $\mathrm{i}$ en anden faldgrube, hvor han undervurderer sprogets kommunikative funktion og samtidig afskærer sig fra en teori, der kan føre til politisk praksis. 
I det kunstneriske udtryks undsigelse af det bestående finder Adorno utopien, som betegnes med begrebet "mimesis". Hermed udtrykker Adorno den tanke, at utopien ikke positivt kan formuleres, uden at den forråder sit indhold, men at kunsten i sin negation af det bestående lader mulighederne for en alternativ eksistens skinne igennem. Alternativet hænges op på et begreb om natur og fornuft, som af ovennævnte grunde heller ikke kan konkretiseres.

Adorno undgår klogt den rousseauske fristelse at vende tilbage til et umiddelbart naturbegreb, fordi der intet umiddelbart gives. Alligevel beholder han i mimesis-begrebet et mystisk og pả mange måder nostalgisk naturideal. Habermas taler med en vis ret om Adornos fare for med sit naturbegreb at ende i en form for dødsdrift (92).

Bag Adornos mimesis-begreb ligger Freuds tanker om lystprincippet. Lystprincippet kan imidlertid ikke i sig selv angive nogen vej mod et alternativt samfund. Kun ved politisk at arbejde på en ændring af realitetsprincippets dominans og specifikke udformning, kan man hảbe på at ophæve undertrykkelsen af naturen.

I "Dialektik der Aufklänung" demonstrerer Horkheimer og Adorno på den ene side, hvorledes den rationelle tænkning har ført til undertrykkelse af såvel den ydre som den indre natur, og på den anden side hvordan et alternativt oplysningsbegreb, hvori naturen integreres uden at blive undertrykt, kan tjene den menneskelige frigørelse. Der opereres sảledes med to fornuftsbegreber. Det ene er den repressive, instrumentelle ratio, som er hentet fra naturvidenskaberne, det andet er den sande fornuft, som taler i utopien. Frankfurterskolen bekender sig sảledes äbent til en kritisk oplysningsfilosofi, jvfr. Jørgen K. Bukdahls ord: "Frankfurterskolen er slet og ret en problembevidst oplysningsfilosofi" (93). Den herskende repression fordømmes ud fra en forestilling om en sand menneskelig eksistens. Det værendes slette almenhed konfronteres med begrebet om det sande almene.

Personligt tror jeg, at det er umuligt at opstille kvalitative kriterier uden en form for fornuftsbegreb. F.eks. ville der ikke være nogen grund til at angribe den bestảende ulighed, hvis man ikke troede, at en ligelig fordeling af goderne var fornuftig. Et sådant begreb bygger pả en teori om den menneskelige natur, og hvad der er bedst for den.

Det betyder imidlertid ikke, at fornuften er en platonisk idé, som eksisterer uden for den historiske proces. Den indgår $\mathrm{i}$ den og ændrer karakter $\mathrm{i}$ forbindelse med forandringer i produktivkræfter og produktionsforhold. Den er et foranderligt begreb, som kan anvendes til korrektion af de herskende politiske forhold og tanker. Den fastholder etikkens forankring i politikken, samtidig med at den arbejder på at gøre politikken e tisk.

Adornos fornuftsbegreb kommer derimod til at svæve uden for den 
historiske situation, fordi han anser hele samfundet for $\mathrm{u}$-fornuftigt. Fornuftsbegrebet knyttes ikke til modsætninger i samfundsformationen, men distancerer sig fra den og placerer sig i utopiens historiske tomrum. Derved bliver det metafysisk, og mulighederne for revolutionær politisk praksis udelukkes.

I det hele taget mener jeg, man bør sige fra over for Frankfurterskolens kritik af enhver form for systematisk tænkning. Den kritiske teoris afsløring af den instrumentelle fornuft og dens forhold til den borgerlige ideologi har været af uvurderlig værdi i det opgør, der har fundet sted i de sidste par år med den positivistiske videnskab. Men ikke enhver teori behøver at være repressiv over for de fænomener, den beskriver, og enhver revolutionær politisk strategi har behov for en videnskabelig teori.

Adornos tanker om den forvaltede verden er for det første objektivt set ikke rigtige, idet de tilslører de modsætninger, der reelt findes i samfundet. For det andet bestyrker de folk i en resignation, som uundgåeligt kommer til at række hånd til magthavernes interesser. Den kritiske teori bliver således en slags selvopfyldende profeti, som mod sin hensigt ender med at bekræfte det, den kritiserer.

Det er ikke teorien i sig selv, der skal bekæmpes, men en bestemt videnskabelig, positivistisk, og til denne kamp er der behov for en alternativ teori, som ikke er repressiv, men frigørende.

Det samme kan hævdes over for Adornos æstetiske teori. Adorno har med "Ästhetische Theorie" leveret en af de mest indtrængende analyser af det specifikke i kunsten, og i f.eks. sine essays om Balzac, Hölderlin og Beckett har han givet nogle af de mest inspirerende litterære fortolkninger, jeg nogensinde er stødt på.

Men netop en dialektisk teori, der uundgåeligt også er en kritisk teori, er forpligtet til at forholde sig konkret til den samfundsmæssige virkelighed, som kunsten definerer sig i forhold til. Med sit utopibegreb har Adorno delvis anbragt sig uden for denne virkelighed, og hans kunstopfattelse er blevet låst fast $i$ en modemistisk position. Adornos arbejde med æstetikken er beundringsværdigt, men bor og skal føres videre. Det, der er brug for i dag, er en virkelig politisk og æstetisk teori.

Claus Secher, december 1971 


\section{Noter:}

1) se f.eks. Tradisjonell og kritisk teori i Gyldendals Studiefakler. Oslo 1970.

2) En skelnen mellem hvad der står for de enkelte forfatteres regning er efter min mening både umulig og uvidenskabelig.

3) "Das Programm der Aufklärung war die Entzauberung der Welt. Sie wollte die Mythen auflösen und Einbildung durch Wissen stürzen".

4) "Die Aufklärung verhält sich zu den Dingeñ wie der Diktator zu den Menschen. Der Mann der Wissenschaft kennt die Dinge, insofern er sie machen kann".

5) "Durch solches Eingedenken der Natur im Subjekt, in dessen Volzug die verkennte Wahrheit aller Kultur beschlossen liegt, ist Aufklärung der Herrschaft überhaupt entgegensetzt. ..".

6) "Das Elend als Gegensatz von Macht und Ohnmacht wächst ins Ungemessene zusammen mit der Kapazität, alles Elend dauernd abzuschaffen".

7) Det samme gælder Herbert Marcuse i "Det endimensionale menneske".

8) Dette referat er en kort parafrasering af pp. 88-94. En mere udforlig og klarere påvisning af modsigelserne hos Kant er givet af Georg Lukács: Historia och klassemedvetande. Bo Cavefors Bokförlag 1968.

9) "Juliette hat die Wissenschaft zum Credo".

10) "Indem die mitleidlosen Lehren die Identität von Herrschaft und Vernunft verkünden, sind sie barmherziger als jene der moralischen Lakaien des Bürgertums".

11) "Wo Menschliches werden will wie Natur, verhärtet es sich zugleich gegen sie".

12) "Der bürgerliche Antisemitismus hat einen spezifischen ökonomischen Grund: die Verkleidung der Herrschaft in Produktion".

13) "Anstelle der antisemitischen Psychologie ist weithin das blosse Ja" zum faschistischen Tickett getreten, dem Inventar der Parolen der streitbaren Grossindustrie".

14) Unweigerlich reproduziert jede einzelne Manifestation der Kulturindustrie die Menschen als das, wozu die ganze sie gemacht hat".

$15)$ "die falsche Identität von Allgemeinem und Besonderem".

16) "Die grossen Künstler waren niemals jene, die Stil am bruchlosesten und vollkommensten verkörperten, sondern jene, die den Stil als Härte gegen dan chaotischen Ausdruck von Leiden, als negative Wahrheit, in ihr Werk aufnahmen".

17) "Die Reinheit der bürgerlichen Kunst, die sich als Reich der Freiheit im Gegensatz zur materiellen Praxis hypostasierte, war von Anbeginn mit dem Ausschluss der Unterklasse erkauft, deren Sache, der richtigen Allgemeinheit, die Kunst gerade durch die Freiheit von den Zwecken der falschen Allgemeinheit die Treue hält.

18) "Solange Kunst darauf verzichtet, als Erkenntnis zu gelten, und sich dadurch von der Praxis abschliesst, wird sie von der gesellschaftlichen Praxis toleriert wie die Lust".

19) Se D.d.A. p. 47

20) "Sie (filosofien) erkennt keine abstrakten Normen oder Ziele an, die im Gegensatz $z u$ den geltenden praktikabel wären".

21) Kritisk teori, p. 85. En antologi over Frankfurterskolen i filosofi og sociologi. Gyldendal. Oslo 1970.

22) "Heideggers Einordnung in den Hitlerschen Führerstaat war kein Akt des Opportunismus, sondern folgte aus einer Philosophie die Sein und Führer identifizierte".

23) "Praksis, welche die Herstellung einer vernünftigen und mündigen Menschheit bezweckt, verharrt im Bann des Heil ohne eine das Ganze in seiner Unwahrheit denkende Theorie".

24) "Nur Denken, das ohne Mentalreservat, ohne Illusion des inneren Königtums seine Funktionslosigkeit und Ohnmacht sich eingesteht, erhascht vielleicht einen Blick in eine Ordnung des Möglichen, des Nichtseienden, wo die Menschen und Dinge an ihrem rechten Ort wären". 
25) se $\overline{A s t h e t i s c h e}$ Theorie, p. 541. Begrebet parataxis vil jeg komme nærmere ind på i det følgende med henblik på essayet om Hölderlin.

26) "Er (essayet) ist, was er von Beginn war, die kritische Form par excellence; und zwar als immanenter Kritik geistiger Gebilde, als Konf rontation dessen, was sie sind, mit ihrem Begriff, Ideologikritik".

27) "Produktiv war Asthetik nur solange, sie die Distanz von der Empirie ungeschmälert achtete. ..".

29) "In der verwalteten Welt ist Neutralisierung universal".

30) Oversættelsen af de tyske termer såvel som denne korte fremstilling af visse hovedpunkter i den tyske, idealistiske æstetik bygger på Georg Lukács: Historia och klassmedvetande; termerne nævnes p. 208.

32) Lige så polemisk Adorno er over for den ældre Lukács, lige så influeret er han af den unge Lukács.

33) "was ohne Begriff allgemein gefällt", cit. efter Ä.T. p. 247.

34) se Oskar Hansens indledning til Hegel i Berlingske filosofibibliotek, p. 47.

35) "Hat seine (Hegels) Konzeption Geschichte mit der Wahrheit glücklich vermittelt, so ist ihre eigene Wahrheit vom Unglück der Geschichte nicht zu isolieren".

36) Denne polemik vil blive uddybet i et senere afsnit.

37) se A.T. p. 21.

38) jvfr. Tel Quel-gruppens og Lacans påvisning af ligheden mellem tekstproduktion og drømmeproduktion.

39) "Wird erlangte Sublimierung und Integration zum Ein und Allen des Kunstwerks gemacht, so verliert es die Kraft, durch die es das Dasein übersteigt, vom dem es durch seine blosse Existenz sich lossagt".

40) "Form wirkt als Magnet, der die Elemente aus der Empirie in einer Weise ordnet, die dem Zusammenhang ihrer ausserästhetischen Existenz entfremdet, und nur dadurch mögen sie der ausserästhetischen Essenz mächtig werden".

41) Eksemplet er hentet fra Ä.T., p. 342.

42) "Sartres Stücke sind Vehikel dessen, was der Autor sagen will, zurückgeblieben hinter der Evolution der ästhetischen Formen".

43) "Indem noch der Völkermord in engagierter Literatur zum Kulturbesitz wird, fällt es leichter, weiter mitzuspielen in der kultur, die den Mord gebar".

44) "Es soll anders sein".

45) "Auf seine (Brechts) Wirkung trifft die angelsächsische Formel vom preaching to the saved zu". A.T., p. 360 .

46) "Noch der emphatische Ideebegriff des Idealismus relegiert die Kunstwerke zu Exempeln der Idee als eines Immergleichen. ..".

47) "Vom rückhaltloser Individuation erhofft sich das lyrische Gebilde das Allgemeine".

48) "Formal sind sie (kunstværkerne), unabhängig vom dem was sie sagen, Ideologi darin, dass sie a priori Geistiges als ein von den Bedingungen seiner materiellen Produktion Unabhängiges und darum höher Geartetes setzen und über die uralte Schuld in der Trennung körperlicher und geistiger Arbeit täuschen.

49) se Jørgen K. Bukdahl: Materialisme, etik og kunst: Theodor W. Adornos kritikbegreb. En referensramme til "Tale om lyrik og samfund. Kritik 13, p. $94 \mathrm{f}$.

50) "'Das Furchtbare blickt aus Schönheit selbst als der Zwang, der von der Form ausstrahlt".

51) "Auch um des Schönen willen ist kein Schönes mehr".

52) "Die Anamnesis der Freiheit im Naturschönen führt irre, weil sie Freiheit im älteren Unfreien sich erhofft".

53) "Treu ist Kunst der erscheinenden Natur einzig, wo sie Landschaft vergegenwärtigt im Ausdruck ihrer eigenen Negativität".

54) Bukdahl oversætter "Geist" med ordet bevidsthedsform. Kritik 13, p. 99.

55) "je substantieller Vergeistigung in der Kunst wurde, desto energischer hat sie, in Benjamins Theorie nicht anders als in Becketts dichterischer Praxis, dem Geist, der Idee abgesagt".

56) "Er verkörpert die gesellschaftlichen Produktivkräfte, ohne dabei notwendig an die von den Produktionsverhältnissen diktierten Zensuren gebunden zu sein, die er durch die Konsequenz des Metiers immer auch kritisiert". 
57) "Der Formbegriff markiert die schroffe Antithese der Kunst zum empirischen Leben, in welchem ihr Daseinsrecht ungewiss ward. Kunst hat soviel Chance wie die Form und nicht mehr".

58) "Form konvergiert mit Kritik. Sie ist das an den Kunstwerken, wodurch diese sich als kritisch in sich selbst erweisen".

59) se N.z.L. II, p. 214.

60) "Jedes Kunstwerk ist ein System von Unvereinbarkeit".

61) se essayet "Valérys Abweichungen", N.z.L. II, p. 42-95.

62) se "Voraussetzungen", N.z.L. III, p. 136-156.

63) "Die höchsten lyrischen Gebilde sind darum die, in denen das Subjekt, ohne Rest von blossem Stoff, in der Sprache tönt, bis die Sprache selber laut wird".

64) "Der Augenblick der Selbstvergessenheit, in dem das Subjekt in der Sprache undertaucht, ist nicht dessen Opfer ans Sein".

65) "Phänomenologi der Kunst scheitert an die Voraussetzung von Veraussetzungslosigkeit. Kunst spottet der Versuche, sie auf reine Wesenhaftigkeit zu vereidigen. Sie ist nicht was sie von je soll gewesen sein, sondern was sie geworden ist".

66) "Ausdrucksvoll ist Kunst, wo aus ihr, subjektiv vermittelt, ein objektives spricht: Trauer, Energie, Sehnsucht. Ausdruck ist das klagende Gesicht der Werke".

67) "Ausdruck haben sie (kunstværkerne), nicht wo sie das Subjekt mitteilen, sondern wo sie von der Urgeschichte der Subjektivität, der von Beseelung erzittern," Ä.T. p. 172.

68) jvfr. E. Auerbachs: Mimesis. Dargestellte Wirklichkeit in der abendländischen Literatur.

69) Mimesis er således lig anti-mimesis i den forstand, Niels Egebak med udgangspunkt i Tel Quel-gruppens tegnteori har skildret begrebet. I det hele taget minder Adornos tanker om det poetiske tegns tvetydighed meget om Tel Quel-gruppens.

70) "Für die Utopi gilt das Bilderverbot so streng wie für die messianische Zukunft der Juden".

71) "die schimärische Sehnsucht der Sprache nach dem Unmöglichen wird zum Ausdruck der unstillbaren erotischen Sehnsucht des Subjekts, das im anderen seiner selbst sich entledigt".

72) "Die Ursprache aber ist die Dichtung als Stiftung des Seins".

73) "Er (Hölderlin) war allergisch gegen das je zu enwartende, vorweg schon Eingefangene und Tauschbare des sprachlichen Convenus".

75) Kommunikation, das universale Gesetz der Clichés, bekundet, dass keine Kommunikation mehr sei".

76) 'Wie die wache Erfahrung nach intensiver Lektüre Kafkas allerorten Situationen aus seinen Romanen zu beobachten meint, so bewirkt Becketts Sprache eine heilsame Erkrankung des Erkrankten: wer sich selbst zuhört, bangt, ob er nicht ebenso redet".

77) "Einst, in geschlossenen Gesellschaften, habe jedes Kunstwerk Ort, Funktion und Legitimation besessen und sei darum mit Geschlossenheit gesegnet worden, währende heute ins Leere gebaut würde und das Kunstwerk zum Scheitern auch in sich verurteilt".

78) Ä.T., p. 241.

79) "Aber Valéry zeigt sich darin mit dem Neoklassicismus verschworen, dass er von aussen gestzte Formen rechtfertigt, unabhängig von der Immanenz der Form in der Gesetzmässigkeit des je einzelnen Gebildes".

80) se artiklerne "Prolog zum Fernsehen" og "Fernsehen als Ideologi" i Eingriffe. Neun kritische Modelle.

81) "Der Schluss von philosophischen Materialismus auf ästhetischen Realismus ist falsch".

82) 'Wo immer gegen Dekadenz gewettert wird, wiederholt sich jene Flucht. Lukács wird zu ihr gezwungen durch einen Zustand, in dem gesellschaftliches Unrecht fortwährt, während es officiell für abgeschafft erklärt ist".

83) "Nicht ist an dem einzelnen Subjekt, durch Wahl und Entschluss über die kollektiv determinierte Einsamkeit hinauszugelangen".

84) "der erste solche paysan de Paris". 
85) "Der Realismus, dem auch idealisch Gesonnene nachhängen, ist nicht primär, sondern abgeleitet: Realismus aus Realitätsverlust. Epik, die des Gegenständlichen, das sie zu bergen trachtet, nicht mehr mächtig ist, muss es durch ihren Habitus übertreiben, die Welt mit exaggerierter Genaugigkeit beschreiben, eben weil sie fremd geworden ist, nicht mehr in Leibnähe sich halten lässt".

86) Versuch das Endspiel zu verstehen. N.z.L. p. 202.

87) "Die protestlose Darstellung gegenwärtiger Regression protestiert gegen eine Verfassung der Welt, die so willfährig dem Gesetz von Regression gehorcht, dass sie eigentlich schon über keinen $G$ egenbegriff mehr verfügt, der jener vorzuhalten wäre".

88) "Wenn aber Wahrheit das Ganze ist, das Ganze aber nur das Unwesen der Gesellschaft, dann wird Subjektivität in der Bestimmung der Freiheit zur Utopie".

89) "Wenn Theorie Handlungsaskese bedeutet, so ist Utopie deren genaue Perversion".

90) häften för Kritiska Studier 5 - 1969, p. 28.

91) Det er kun angrebet på Adornos totalitetsbegreb, jeg beskæftiger mig med hos Willms og Therborn. Derfor refererer jeg ikke artiklerne $i$ deres helhed og tager heller ikke stilling til forfatternes personlige synspunkter.

92) se Jurgen Habermas: Ein philosophierender Intellektueller. Über Theodor W. Adorno p. 42.

93) Jørgen K. Bukdahl: Tradition og selvstændighed: Optakt til Freud. (Hermeneutiske landevindinger 2). Kritik 18, p. 139.

\section{Bibliografi:}

Theodor W. Adorno: Gesammelte Schriften 7. Ästhetische Theorie. Suhrkamp. Frankfurt am Main 1970.

Th. W. Adorno: Noten zur Literatur I-III. Suhrkamp. Frankfurt am Main 1969.

Th. W. Adorno: Eingriffe. Neun kritische Modelle. edition Suhrkamp. Frankfurt a. M. 1971.

Th. W. Adorno: Sosiologi og empirisk forskning; fra Horkheimer, Marcuse, Adorno, Habermas: Kritisk teori. Gyldendals studiefakler. Oslo 1970.

Max Horkheimer og Th. W. Adorno: Dialektik der Aufklärung. Philosophische Fragmente. S. Fischer Verlag. Frankfurt a. Main 1969.

Jørgen K. Bukdahl: Materialisme, etik og kunst. Theodor W. Adornos kritikbegreb. Kritik 13. København 1970.

Jørgen K. Bukdahl: Tradition og selvstcendighed. Optakt til Freud. (Hermeneutiske landevindinger 2). Kritik 18. København 1971.

Oskar Hansen: Forord til Hegel. Berlingske Filosofi Bibliotek. København 1971.

Georg Lukács: Historia och klassmedvetande. Bo Cavefors Bokförlag. Stockholm 1968.

Göran Therborn: häften för Kritiska Studier 5 og $6-1969$.

(antologien): Uber Theodor W. Adorno. edition Suhrkamp Frankfurt a. M. 1970.

William K. Wimsatt, Jr. og Cleanth Brooks: Literary Criticism. A Short History. Vintage Books. New York 1957. 